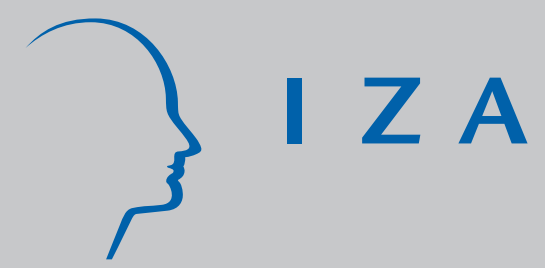

IZA DP No. 7996

Identifying the Causal Effect of Alcohol Abuse on the Perpetration of Intimate Partner Violence by Men Using a Natural Experiment

Susan Averett

Yang Wang

February 2014 


\title{
Identifying the Causal Effect of Alcohol Abuse on the Perpetration of Intimate Partner Violence by Men Using a Natural Experiment
}

\author{
Susan Averett \\ Lafayette College \\ and IZA \\ Yang Wang \\ Lafayette College
}

Discussion Paper No. 7996

February 2014

IZA

P.O. Box 7240

53072 Bonn

Germany

Phone: +49-228-3894-0

Fax: +49-228-3894-180

E-mail: iza@iza.org

\begin{abstract}
Any opinions expressed here are those of the author(s) and not those of IZA. Research published in this series may include views on policy, but the institute itself takes no institutional policy positions. The IZA research network is committed to the IZA Guiding Principles of Research Integrity.

The Institute for the Study of Labor (IZA) in Bonn is a local and virtual international research center and a place of communication between science, politics and business. IZA is an independent nonprofit organization supported by Deutsche Post Foundation. The center is associated with the University of Bonn and offers a stimulating research environment through its international network, workshops and conferences, data service, project support, research visits and doctoral program. IZA engages in (i) original and internationally competitive research in all fields of labor economics, (ii) development of policy concepts, and (iii) dissemination of research results and concepts to the interested public.
\end{abstract}

IZA Discussion Papers often represent preliminary work and are circulated to encourage discussion. Citation of such a paper should account for its provisional character. A revised version may be available directly from the author. 
IZA Discussion Paper No. 7996

February 2014

\section{ABSTRACT}

\section{Identifying the Causal Effect of Alcohol Abuse on the Perpetration of Intimate Partner Violence by Men Using a Natural Experiment}

Intimate partner violence (IPV) is widespread among women, with substantial and longlasting negative consequences. Researchers have documented a strong positive correlation between alcohol abuse and IPV. Yet prior researchers have struggled with the problem of the potential endogeneity of alcohol abuse. In this paper, we deal with this problem by exploring a unique instrumental variable - the September 11 terrorist attack (9/11) - in Wave III of the National Longitudinal Study of Adolescent Health. 9/11 was found in our data to lead to a significant increase in the frequency of alcohol abuse for respondents interviewed just after 9/11 compared to those interviewed before. Our OLS results indeed confirm earlier research of a strong positive correlation between alcohol abuse and IPV. However, the 2SLS results show no statistically significant effect of alcohol abuse on IPV. These results indicate that alcohol abuse might not have causal effects on IPV, and therefore have important policy implications.

JEL Classification: I12, I18, J12

Keywords: intimate partner violence, alcohol abuse, 9/11, instrumental variable

Corresponding author:

Susan Averett

Department of Economics

Lafayette College

Easton, PA 18042

USA

E-mail: averetts@lafayette.edu 


\section{Introduction and Previous Research}

Intimate partner violence (IPV) is widespread nationally and globally (Garcia-Moreno et al., 2006; Ruiz-Perez et al., 2007). 5.3 million IPV victimizations occur among U.S. women aged 18 and older each year (CDC, 2003) and 25 to 54 percent of women in the U.S. report exposure to IPV in their adult lifetime, making it four times more common than breast cancer (Thompson et al., 2006). Worldwide, according to the World Health Organization (WHO), IPV is the most common type of violence against women - more common than rape or other violent attacks by a stranger (WHO, 2005).

Although there is no accepted formal definition, IPV includes both physical violence and forced sexual activity. It has substantial and long-lasting negative consequences, even after the abuse has ended (Campbell, 2002), and it has put increased strain on societies (Sabia, 2004; Thompson, et al., 2006). Studies show that somewhere between 40 and 60 percent of murders of women in North America are due to an intimate partner (Campbell, 2002), and among the 2 million injuries caused by IPV, more than 550,000 of them require medical attention (Tjaden and Thoennes, 2000). The costs of IPV in the U.S. have been estimated to be 5.8 billion dollars per year, including both physical and mental medical costs and loss of work productivity (CDC, National Center for Injury Prevention and Control, 2003) $!^{1}$

Because of its prevalence and high costs, IPV is an issue of grave concern to policy makers. For example, in 1994, the U.S. federal government passed the Violence Against Women Act (VAWA) which, among other provisions, provides $\$ 1.6$ billion toward investigation and prosecution of violent crimes against women (and in some cases men), and imposes automatic and mandatory restitution on those convicted, and allows victims to pursue a civil claim for damages if their case is not prosecuted in criminal court. The VAWA also established the Office on Violence Against Women within the Department of Justice. In March of 2013, Congress reauthorized the VAWA and included provisions

\footnotetext{
${ }^{1}$ This number does not yet include negative effects of IPV on the next generation. According to Aizer (2011) who exploits variation in the enforcement of laws against IPV for identification, hospitalization due to IPV for pregnant women leads to statistically significant reductions in birth weight for newborns.
} 
for same sex couples and immigrants. Internationally, a stated priority of the United Nation's fourth World Conference on Women held in Beijing in 1995 was to study the causes and consequences of violence against women. Consequently, governments around the world were urged to promote research in this area (UN, 1995).

Many factors may contribute to the occurrence of IPV (see, e.g., Tauchen, Witte, and Long, 1992; Farmer and Tiefenthaler, 1997; Iyengar, 2009; Pollak, 2004; Card and Dahl, 2011; Kiss et al., 2012; Hidrobo and Fernald, 2013). The focus of this paper is on one factor which has an established strong positive correlation with IPV, namely, alcohol abuse (e.g., Johnson, 2001; Graham et al., 2011; Tumwesigye et al, 2012).

Three explanations for why we might expect a link between violence and excess alcohol consumption have been put forth by researchers. First, excess alcohol consumption and the ensuing chemical/psychopharmacological effect can provide a man with a false sense of bravery, a heightened sense of excitability and a reduced moral sensibility. These changes thus increase the probability of IPV.2 Second, a man may use his inebriation as an excuse for his violent behavior since behaving violently while drunk may be more socially acceptable (to the extent that violence is acceptable). Finally, it is possible that a third factor may cause a man to both drink heavily and commit IPV (Markowitz and Grossman, 1998; Markowitz, 2000; Caetano et al., 2001, 2008).

Empirically, an overview of studies on IPV shows that, when the violence occurred, men were drinking in about 45 percent of the cases (ranging from 6 to 57 percent) and women were drinking in about 20 percent of the cases (ranging from 10 to 27 percent) (Roizen 1993). Although there is an extensive literature linking alcohol to IPV (e.g., Johnson, 2001; White and Chen, 2002; Graham et al., 2011; Tumwesigye et al, 2012), much of this literature has not been able to establish a causal relationship (e.g., Caetano et al., 2001; Johnson, 2001; Connor et al., 2009; Djikanovic et al., 2010).

Establishing whether there is a causal effect of alcohol abuse on IPV has been challenging due to the possible endogeneity issue. There might exist some unobserved or

\footnotetext{
${ }^{2}$ Although we refer to the man as the perpetrator of the IPV and focus on young adult male's IPV behavior in this paper, women have also been known to commit IPV.
} 
unobservable personal characteristics that cause both alcohol abuse and other risky behaviors such as IPV; the reported alcohol abuse might be a noisy measure of the actual level of alcohol abuse; and one could even question the direction of causality — perhaps being violent makes one more prone to drink. In these cases, OLS models that treat alcohol abuse as exogenous will result in inconsistent estimates of the impact of alcohol abuse on violent behavior (Powell et al., 2002).

Despite the challenges noted above, several studies have made notable efforts towards identifying the causal effect of alcohol abuse on IPV. In one of the earliest economics studies on this topic, Markowitz (2000) examines the relationship between price of alcohol and incidence of domestic violence using data from the U.S. National Family Violence Survey. Using a reduced-form framework and an individual-level fixed effects model to control for unobserved characteristics, she finds that an increase in the price of alcohol, as measured by a weighted average of the price of alcohol from beer, wine, and liquor, reduces IPV by husbands aimed at their wives ${ }^{3}$ This study is noteworthy for its focus on establishing a causal relationship, but because the author does not have information on alcohol consumption in her data she cannot directly link the price of alcohol to how much the husbands actually drank or even if they drank.

Sabia (2004) extends Markowitz's work in several ways. Using data from the Fragile Families Survey, he examines the effect of alcohol consumption of men on violence perpetrated to new mothers and pregnant women. He employs several empirical approaches including using state level liquor taxes and state laws on drunk driving to identify variation in alcohol use as instrumental variables and concludes that it is unlikely that alcohol use is the cause of the violence perpetrated towards the women in the sample. Rather, unobservable characteristics of the father may be correlated with the likelihood that he abuses pregnant women and/or new mothers and that he is a heavy drinker.

More recently, using a natural experiment to identify exogenous variation in alcohol consumption, Herttua (2010) documents that lower alcohol prices increased domestic

\footnotetext{
${ }^{3}$ A related body of research suggests that access to alcohol and alcohol consumption increase criminal behavior or violent injury, particularly among young adults (Markowitz, 2001; Powell et al., 2002; Matthews et al., 2006; Carpenter and Dobkin, 2008).
} 
violence in the Helsinki Finland metropolitan area. Finally, Livingston (2011) uses aggregate panel data fielded in Australian to determine the relationship between alcohol outlet density and domestic violence in a fixed-effects framework. He reports a positive relationship between alcohol outlet density and domestic violence..$^{4}$

Because of the paucity of studies using plausible identification strategies to uncover the causal effect of drinking on IPV, and the conflicting results from these studies, researchers have questioned whether we know enough about the causes of IPV to advocate particular types of treatments (Gil-Gonzlez et al., 2006). Yet numerous programs already exist to mitigate IPV by lowering alcohol use; i.e., these programs make the assumption that alcohol is one of the causes of IPV and that treatment for alcoholism will help lower the occurrence of IPV (O'Farrel et al., 2004). Clearly, understanding the causes of IPV is important if policymakers are interested in designing effective policies aimed at reducing its incidence. This paper adds to this literature by using a more contemporary data set and exploiting a new instrument to identify the causal effect of alcohol abuse on IPV perpetrated by men.

We use data from Wave III of the National Longitudinal Study of Adolescent Health (AddHealth) fielded in 2001 and 2002. Our strategy for identifying the effect of alcohol abuse on IPV is to use a unique instrumental variable available in our data. Specifically, during Wave III of AddHealth, the September 11 terrorist attack (hereafter 9/11) occurred $!^{5}$ We hypothesize that this exogenous event, unprecedented and unexpected, had a significant impact on the frequency of individuals' alcohol abuse.

Indeed, there has been ample media coverage on the effect of 9/11 on alcohol abus $\mathrm{6}^{6}$

\footnotetext{
${ }^{4}$ Durrance, Golden, and Cook (2011) estimate the direct relationship between alcohol taxes, and the most extreme form of violence against women, homicide. Although they find evidence that alcohol taxes reduce alcohol consumption, they do not find a significant effect of alcohol taxes on female homicide.

${ }^{5} 9 / 11$ has been used as an instrumental variable by other studies. Averett and Wang (2012) and Wang and Yang (2012) use 9/11 as their IV and find that crisis-induced depression leads to increased sexual activities and engagement in risky sex for young women, and reduced physical activity and increased fast-food restaurant visits for young adults, respectively.

${ }^{6}$ See, for example, the story of NYC firefighters (http://www.firehouse.com/ article/10466012/fdny-was-faced-with-alcohol-drug-abuse-problems-following-9-11, last accessed on 01/29/2014) and the report of a survey of over 1,000 residents of lower NYC conducted $5-8$ weeks post 9/11 (http://www.examiner.com/article/ impact-of-9-11-on-alcohol-use-the-interplay-of-stress-anxiety-and-drinking, last
} 
Columbia University's National Center on Addiction and Substance Abuse reported that by December 2001, 13 states had already detected an increased demand for alcohol and drug treatment, and the number increased to 23 by April, 2002 (CASA, 2001). Actually, researchers have found substantial and significant effects of disasters on alcohol and other substance abuse, following events such as 9/11 (Smith, et al., 1999; Vlahov et al., 2002, 2004; Joseph, et al., 2011).

Because previous research has established that predictors of IPV vary by gender (Markowitz, 2000; Archer, 2002; Gomez, 2011), and men are more likely to have been drinking when engaging in IPV as compared to women (Caetano et al, 2008), we focus our analysis on young adult men. As expected, $9 / 11$ is found in our data to lead to a statistically and economically significant increase in the frequency of alcohol abuse for respondents interviewed just after 9/11 compared to those interviewed before, even though otherwise both groups shared similar characteristics. Combining this first stage results with the second stage estimation of the effect of (instrumented) alcohol abuse on IPV, we are able to demonstrate the importance of disentangling correlation from causation.

Specifically, the OLS results confirm earlier research of a strong positive correlation between alcohol abuse and IPV. However, the 2SLS results, robust to various specification checks, show that this OLS effect might be spurious - in the 2SLS models there is no statistically significant effect of alcohol abuse on IPV. This result suggests that policymakers should use caution when designing policies aimed at reducing IPV — alcohol may not be a causal factor.

The rest of the paper proceeds as follows. In the next two sections, we present our econometric model and then introduce our data. Following that we discuss our estimation results. Finally, we provide some concluding remarks.

accessed on 01/29/2014). Unsurprisingly, 9/11 has impacts on various aspects of people's life, such as their attitudes towards minorities (e.g., Aslund and Rooth, 2005). 


\section{Econometric Model}

We start our analysis of the relationship between IPV and alcohol abuse among young men using the following OLS model:

$$
y_{i}=\beta_{0}+\beta_{1} \mathrm{AA}_{i}+\mathbf{x}_{i}^{\prime} \beta_{2}+\epsilon_{i}
$$

where $\epsilon_{i}$ is the mean-zero error term for young man $i, \mathrm{AA}_{i}$ is a variable measuring this young man's engagement in alcohol abuse which could be potentially endogenous, $\mathbf{x}_{i}$ is a vector of his characteristics, and $y_{i}$ refers to our outcome variables - measures of IPV.

As mentioned in the Introduction, to deal with the potential endogeneity of alcohol abuse, in this study we explore the exogenous nature of $9 / 11$ and use it to instrument young adult men's alcohol abuse when applying a two-stage least squares (2SLS) estimator to the following regression model:

$$
\begin{aligned}
y_{i} & =\beta_{0}+\beta_{1} \mathrm{AA}_{i}+\mathbf{x}_{i}^{\prime} \beta_{2}+\epsilon_{i}, \\
\mathrm{AA}_{i} & =\alpha_{0}+\alpha_{1} z_{i}+\mathbf{x}_{i}^{\prime} \alpha_{2}+u_{i},
\end{aligned}
$$

where the first equation is exactly the same as the OLS regression model, while the second equation shows the first-stage specification of the 2SLS estimator. $u_{i}$ is the mean zero disturbance term, and the variable $z_{i}$ is the IV for $\mathrm{AA}_{i}$ which measures the number of days between the interview dates and September 11, 2001. In both equations, the vector $\mathbf{x}_{i}$ denotes the set of variables controlling for young man $i$ 's characteristics to be discussed in the following section.

\section{Data}

Our data are from the Wave III (fielded from July 2001 to April 2002) of the National Longitudinal Study of Adolescent Health (AddHealth). AddHealth is a school-based longitudinal study of a nationally representative sample of adolescents in grades 7 to 12 
in the United States during the 1994-5 school year.7

Wave III of AddHealth is ideally suited for our analysis for three crucial reasons. First, IPV is more prevalent in early adulthood (Kaura and Allen, 2004), and in Wave III the respondents are 18 to 28 years old, precisely the relevant age group. Second, as described in more detail below, respondents are queried about both their alcohol use and their engagement, if any, in IPV, a feature lacking in many other large scale datasets. Finally, our identification strategy, that the number of days between the interview dates and $9 / 11$ is used as the IV for the potentially endogenous measure of alcohol abuse due to $9 / 11$ 's unexpected nature and its effect on drinking behavior, relies on the timing of the interviews. The availability and the spread of interview dates for Wave III of the AddHealth data make this identification strategy possible.

Respondents for Wave III were asked to compile a relationship roster where they selfidentify all romantic relationships they have had since 1995 (the year 1995 corresponds to Wave I of the AddHealth). In Wave III, recent sexual relationships and relationships that respondents identified as important were selected for a more detailed query of relationship history. Fortunately for our use, whether the relationship was currently occurring at the time of the interview was also reported.

For our sample, we select only those respondents currently in relationships at the time of interview because it could be difficult for respondents to accurately recall all the details of previous relationships, a potential source of measurement error. It is also important for respondents to be in a relationship at the time of the interview because of the unique identification method we use; if the relationship was too far in the past we would not be identifying the effect of alcohol abuse on IPV accurately given the temporal nature upon which our identification strategy rests.

Our continuous measure of alcohol abuse is based on the responses to this question, "During the past two weeks, how many times did you have five or more drinks on a single occasion, for example, in the same evening?" 8 The responses to this question naturally

\footnotetext{
${ }^{7}$ More details on this dataset are available at http://www.cpc.unc.edu/projects/addhealth/ design/designfacts, last accessed on 01/29/2014.

${ }^{8}$ This definition of alcohol abuse has been widely used in the literature on alcohol studies. See, for
} 
range from 0 to 14 .

We use two binary measures of IPV in our analysis, both adapted from the revised Conflicts and Tactics Scale (Straus et al, 1996): violence and hit. The first measure, violence, is based on respondents' answers to the following question, "How often, in the past year, have you threatened PARTNER with violence, pushed or shoved her, or thrown something at her that could hurt?" If they report any positive number, ranging from "once" to "more than 20 times", the variable violence is set to one, otherwise, zero. Similarly, the second measure of IPV, hit, is based on respondents' answers to another question, "How often, in the past year, have you slapped, hit, or kicked PARTNER?" If the answer to this question is a positive number, again ranging from "once" to "more than 20 times", then the variable hit equals one, and otherwise zero.

To deal with the potential omitted variable bias and to ascertain the robustness of our results, we present four specifications for each dependent variable with increasingly more variables included in the $\mathbf{x}_{i}$ vector. We start with the most basic specification where only the (instrumented) alcohol abuse is included. We then add in the 2nd to the 4th specifications: 2) basic demographic variables and basic measures of socioeconomic status: age, whether 21 or older, race (White or not) and ethnicity (whether they have a Hispanic or Latino origin), years of education, a binary indicator of marital status (ever married or not), and a set of categorical measures of income (because income is missing for many respondents, as is not uncommon in survey data, rather than delete those with missing income we generate six binary variables to measure income with five of them indicating income quintiles and the last one indicating that income is missing; the highest income quintile is the reference group); 3) past drinking-related problems, dating and regret, and two measures of mental health, depress and stress, to be explained momentarily; and 4) risky health behaviors and other measures of attitudes towards risk: smoking (whether they had ever regularly smoked for 30 days), marijuana use (whether they used marijuana in the year before the interview), gambling, playing the lottery, and an index of the respondent's attitude towards risk or impulsivity.

example, Bush et al., 1998. 
The variable dating is a binary variable generated using young men's response to the wave I question "You had problems with someone you were dating because you had been drinking." If the answer is positive, then this variable is set to one; and zero otherwise. The variable regret is also a binary variable, generated using young men's response to another Wave I question, "You did something you later regretted because you had been drinking." Again, if the answer is positive, the variable is set to one and zero otherwise. Depress is defined using respondents' answer to the question "You were depressed, during the past seven days, which can be "0, never or rarely; 1 , sometimes; 2 , a lot of time; and 3, most of the time or all the time"; and stress is set to 1 if the respondents have "taken prescription medication in the past 12 months for depression or stress". The variable gamble is a binary variable generated using the responses to the question "Have you ever played casino tables or video games for money such games as craps, blackjack, roulette, slot machines, or video poker?" The variable lottery is a binary variable based on the responses to the question "Have you ever bought lottery tickets, such as daily, scratch-offs, or lotto?" And finally, we use a continuous variable to measure impulsivity (i.e. an individuals attitude towards risk) generated using responses to six different questions, ranging from 6 to 30 with higher scores indicating a greater propensity to take risks. Appendix Table 1 contains details concerning the questions used to generate this variable.

We use these additional variables, which contain a large amount of information on these young men's personal traits and are not typically available in large survey data, to control for, as well as we can, their unobserved heterogeneity - particularly their unobserved propensity for violence. For example, certain personality characteristics such as impulsiveness have been associated with perpetration of intimate partner violence because these characteristics could make individuals less able to regulate or control their behavior (Caetano et al., 2008). In addition, including such a large set of independent variables, in both the first and the second stage of our 2SLS models, helps us to mitigate the possibility that our instruments are mediating the effects of other unobservable factors that influence intimate partner violence. In particular, we include those two 
measures of mental health (depress and stress), which might lead to IPV and could be potentially affected by $9 / 11$, to isolate the effect of alcohol abuse.

We are well aware of the potential endogeneity of some of these variables included in the last two specifications, but the focus of our paper is on the causal effect of alcohol abuse on IPV and the concern over omitted variable bias provides the justification for the inclusion of these potentially endogenous control variables. However, we are careful not to attach a causal interpretation to the coefficients on these variables.

Because Wave III of AddHealth started gradually in July 2001 (with few exceptions), just two months before $9 / 11$, in order to construct comparable "control" and "treatment" groups (in the sense that we could consider $9 / 11$ as the natural treatment), we limit our sample to those young men interviewed within one month before and after 9/11.

Figure 1A shows the distribution of interview dates of Wave III, with the vertical line indicating September 11, 2001, and Figure 1B presents dates of interviews conducted one month before and after 9/11. Note that these two sets of interviews, one month before and after $9 / 11$, are almost of the exact same distribution, consistent with what AddHealth describes as an un-interrupted interview schedule (with the exception of biomarker data, which we do not use in this study, due to restrictions on air travel at that $\operatorname{tim} \oint^{9}$.

In Figure 2, we present the distribution of weekly average frequency of alcohol abuse (i.e., having five or more drinks on one occasion) for our sample — young men in relationship and interviewed one month before and after 9/11. Evidently, there is a sizable jump in the frequency of alcohol abuse after $9 / 11$. This figure gives us confidence that our IV is indeed strong, and its strength is later corroborated by the first stage results of our 2SLS estimation.

To visually see the changes in our IPV measures (violence and hit), we plot the distributions of weekly averages of these two outcome variables one month before and after 9/11 in Figure 3. Unlike Figure 2 where we clearly see a jump in alcohol abuse after

\footnotetext{
${ }^{9}$ Details on effects of $9 / 11$ on biomarker data are available at http://www.cpc. unc. edu/projects/ addhealth/data/guides/biomark.pdf last accessed on 01/29/2014.
} 
$9 / 11$, we do not see sudden increases, following the $9 / 11$, in the frequencies of engaging in either of our two measures of IPV, presaging our 2SLS estimation results ${ }^{10}$

\section{Results}

Table 1 presents summary statistics of all the variables used in this study. The average respondent is about 22 years of age; $73 \%$ of them are 21 years of age or older. Most of our respondents are White (72\%) and 17\% have a Hispanic background. The average education level is about 13 years, and almost $15 \%$ of respondents report being married at the time of interview. $41 \%$ have smoked for at least 30 days in their lives, and about $50 \%$ have used marijuana during the year before the interview.

With respect to measures of the respondents' proclivity to take risks, the average score for risk attitudes/impulsivity is 16.9 , about $65 \%$ have gambled before, and almost $65 \%$ of them have played lottery. Approximately $11 \%$ reported having problems with dating due to drinking and almost $15 \%$ reported having regrets about some drinkingrelated behaviors. The average frequency of being depressed in the past week is close to 0 (never or rarely), and about $3.5 \%$ of our respondents took prescription medication for depression or stress in the year before the interview. The average number of times for our respondents to have more than five drinks on one occasion is about 1.3.

As for the outcome variables, about $17 \%$ of these men reported having hit their partner and about $25 \%$ reported that they had been violent towards their partner. Finally, as designed and consistent with the un-interrupted nature of the AddHealth interview, $50 \%$ of the respondents in our sample were interviewed after $9 / 11$, and the number of days between the interview and 9/11 ranges from -30 for those interviewed one month before $9 / 11$ to 30 for those interviewed one month after.

Because our identification strategy is based on $9 / 11$, we also check whether our sample means are significantly different by respondents' interview dates. Tables $2 \mathrm{a}$ and

\footnotetext{
${ }^{10} \mathrm{~A}$ potential data limitation is that AddHealth does not provide information on the geographic location of each respondent, thus we cannot test whether those living in New York, Connecticut or New Jersey were more affected by the events of $9 / 11$.
} 
$2 \mathrm{~b}$ present the results of regressing each of our independent variables on a continuous variable measuring the number of days between interview and 9/11.11 As we can see, our respondents are largely similar to one another in characteristics regardless of the date of their interview, with only a few exceptions. Respondents interviewed after 9/11 have fewer years of education, are more likely to be in the lowest quintile of the income distribution, but are less likely to be in the middle quintile. They are also more likely to have smoked and used marijuana in the past, more likely to feel depressed, and score higher on the impulsivity measure. Although these few differences mentioned above are statistically significant, the magnitudes of these differences are fairly small compared to the means of those variables.

As noted earlier, the main reason for the similarity in characteristics for respondents interviewed around 9/11 is, as AddHealth emphasizes, that their interview schedule was unaffected by $9 / 11$; and Tables $2 \mathrm{a}$ and $2 \mathrm{~b}$ shows that this is generally the case. Most importantly, those interviewed after 9/11 show a higher frequency of engaging in alcohol abuse (both economically and statistically significant) a finding consistent with the literature and in line with of our IV strategy.

Table 3 presents the OLS estimates for both IPV outcome variables. For each dependent variable, estimation results for all four specifications (I to IV) are reported. Starting with the first four columns, we find that regardless of which specification we use, the effect of alcohol abuse on the probability of hitting the partner is always statistically significant, and the magnitude of this effect stays stable at 1.3 to 1.4 percentage points, which corresponds to a $7.6(1.3 / 17)$ to $8.2(1.4 / 17)$ percent increase in the propensity to hit one's partner (the sample mean for outcome variable hit is 17 percentage points) for each additional occasion of heavy drinking (more than 5 drinks at one time). Contrary to what other researchers have reported (Caetano, 2008), race (being White) is also a significant predictor of hitting one's partner in some specifications, even after controlling for education and income, but the effect is no longer statistically significant in the

\footnotetext{
${ }^{11}$ We also regress each of our independent variable on a dummy variable equal to one if the respondent was interviewed on or after $9 / 11$ and zero otherwise, and the results are qualitatively the same.
} 
specification with the full set of controls.

When we look at the last four columns of the estimation results for the effect of alcohol abuse on the probability of engaging in violence against one's partner, we can see that the results are largely similar to those for the probability of hitting one's partner. The effect of alcohol abuse is always statistically significant with a magnitude ranging from 1.2 to 1.4 percentage points, which translates to a $4.8(1.2 / 24.8)$ to $5.6(1.4 / 24.8)$ percent increase in the propensity to engage in violence against one's partner. As for the control variables, we find that now being White and having past drinking-related problems are consistently associated with statistically significantly higher probabilities of engaging in violence against one's partner, while reporting having purchased lottery tickets predicts lower probabilities, all else equal.

Even though the richness of the AddHealth data allows us to control for many previously unobservable factors, many important factors, which could lead to both violence against one's partner and excessive alcohol consumption, may still be unmeasured. Furthermore, one could question the direction of causality — perhaps being violent makes one more prone to drink; or there may be measurement error in the self-reported alcohol abuse variable. Because of this potential endogeneity, we now turn to the 2SLS estimates.

The first stage results for the 2SLS estimation are reported in Table 4. The coefficients on the variable of interest — number of days between the interview and 9/11 are positive, indicating that as we move from pre-9/11 to post-9/11 individuals are more likely to abuse alcohol (i.e. to have an occasion when they have more than five drinks). This effect is statistically significant everywhere at the $1 \%$ level, indicating that each additional day after $9 / 11$ increases the number of occasions on which the respondent drank five or more drinks by 0.011 to 0.014 across the different specifications for the two outcome variables. The first stage F statistics are also consistently over 10, passing the commonly used threshold (Cameron and Trivedi, 2005). This result that we have a strong first stage is consistent with the literature on the effect of disasters on substance abuse (see the Introduction), and corroborates the pattern of the change in the frequency 
of alcohol abuse before and after 9/11 illustrated in Figure 2.

A look at those control variables shows that White young adult men have a higher probability of alcohol abuse, while being Hispanic lowers this probability. Compared to those in the highest income quintile (the reference group), those in lower ones are less likely to drink heavily. Being married appears to have a protective effect against alcohol abuse; and all the measures of attitude towards risk, whether it is health-related behaviors like smoking and marijuana use or just taking risks in daily life such as gambling and playing the lottery, are, as expected, positive and statistically and economically significant predictors of alcohol abuse.

The estimation results for the second stage of 2SLS are reported in Table 5 . We focus first on the results for young men's probability of hitting their partners (Table 5, first four columns). Clearly, the effect of the instrumented alcohol abuse on the probability of hitting a partner is no longer statistically significant, regardless of which specification we use. The IV standard errors, as expected, are larger than those in the OLS, while the point estimates are somewhat similar to those of OLS. These results indicate that there is unlikely any causal effect of alcohol abuse on the probability of hitting one's partner.

The last four columns of Table 5 show that the coefficients for the instrumented alcohol abuse on the probabilities of other violence against one's intimate partner are no longer statistically significant either, with standard errors of similar magnitude to those in the first four columns while the IV point estimates are larger than the OLS point estimates. These somewhat larger yet imprecisely estimated coefficients lead us to think that it may be difficult to entirely rule out a positive link between alcohol abuse and violence towards one's partner, though the robustness checks we present in the next section make this interpretation very unlikely. A quick look over all the specifications for both outcome variables makes it clear that the effects of all the control variables are the same as those in the OLS.

Combining the information from Tables 3 to 5 leads us to conclude that failure to deal with the endogeneity of alcohol abuse could lead to the erroneous conclusion that alcohol abuse causes IPV. In fact, using our unique, strong, and arguably exogenous IV, 
we show that the positive correlation we observe between alcohol abuse and IPV may very well not be causal, at least not for the young adult men in our sample.

In addition to using the various specifications shown in Tables 3 to 5 , we also conduct several robustness checks. First, we use an alternative instrumental variable. Instead of using the continuous number of days between interview dates and 9/11 as the instrument, we create, based on this continuous number, a binary variable which is set to one for those who were interviewed on or after $9 / 11$, and zero for those interviewed before. The estimation results from the specification with this alternative instrument are reported in Table 6. The OLS results remain the same as those in Table 3, and clearly, the 2SLS results are qualitatively the same as those reported in Table 5. We can still conclude that there is strong evidence that alcohol abuse may not lead to higher probabilities of IPV for this group of young adult males.

Second, we use an alternative measure of alcohol abuse. That is, instead of using the number of days having five or more drinks on a single occasion as the measure of alcohol abuse, we use the responses to the question, "During the past two weeks, how many times did you have four or more drinks on a single occasion, for example, in the same evening?" The estimation results, reported in Table 7, are evidently qualitatively similar to the main ones reported in Tables 3-5. That is, OLS results show statistically significant effects of alcohol abuse on IPV, while 2SLS estimation wipes out the statistical significance. So clearly, our conclusion is not sensitive to the measure of alcohol abuse we use.

Third, instead of using the continuous measure of alcohol abuse, i.e., the number of days with five or more drinks on a single occasion, we create a binary variable equal to one if the number of days is positive, and zero otherwise. This specification examines the effect of alcohol abuse at the extensive margin, instead of the intensive margin. As is clear from Table 8, the estimation results are again qualitatively the same, with significant OLS estimates and insignificant 2SLS results, consistent with our conclusion that alcohol abuse may not be causal to IPV for our sample.

Fourth, to check whether our estimation results are sensitive to the time window we 
choose for the main specification - 30 days before and after $9 / 11$, we construct two different samples where we use 15 days and 45 days as the time window, respectively. We estimate our models using OLS and 2SLS using these two different samples and reach essentially the same conclusion; that is, OLS results show a statistically significant correlation between alcohol abuse and IPV, while the 2SLS results indicate that this correlation is not a causal relationship. These results are reported in Appendix Table 212

Finally, as noted above, the 2SLS coefficients are sometimes larger than the OLS coefficients, which, coupled with the larger standard errors for the 2SLS, could lead one to speculate that the effect of alcohol on IPV could even have been understated by the OLS model. However, our various robustness checks give us confidence that this is very unlikely to be the case.

Our finding that alcohol is likely only a correlate, not a cause, of IPV for the young adult males in our sample is not a universal finding in the economics literature. For example, Markowitz (2000), Herttua (2010), and Livingston (2011), applying different estimation methods to data from various countries, all found that lower alcohol prices or higher alcohol outlet density would lead to higher probability of IPV. Our results, however, are consistent with what is found by Sabia (2004) who also directly analyzed the relationship between alcohol consumption and IPV, just like what we do in this paper, and are also consistent with what is reported by Durrance, Golden, and Cook (2011) who find that alcohol taxes reduce alcohol consumption but there is no significant effect of alcohol taxes on female homicide - the most extreme form of violence against women.

\footnotetext{
${ }^{12}$ We run a placebo test to rule out the possibility of a "September" effect; i.e. to rule out the possibility that our results are driven by something unique to September (the weather, the season, the coming holidays, etc.) instead of $9 / 11$. Specifically, we run the same regressions using the variables from Wave $I V$ of AddHealth and the number of days between interview dates and 9/11/2008 as the IV. In results not shown here, we find no statistically significant effect of the number of days on alcohol abuse for Wave IV. That is, what we find in the first stage of our 2SLS estimation using Wave III data is indeed the effect of 9/11 instead of the effect of September. However, because the question on alcohol abuse in Wave IV uses the past 12 months, instead of the past two weeks, as the time frame, we do not consider this result exactly comparable and therefore are not reporting it here.
} 


\section{Conclusions and Discussion}

IPV is a serious public health issue. It is widespread, and it imposes substantial economic costs on both the victims and society as a whole. It is therefore important to understand the causes, not just the associative factors, underlying IPV, so policymakers can make effective policy recommendations.

Numerous studies have established a strong positive correlation between alcohol abuse and IPV. Yet identifying the causal effect of alcohol abuse on IPV has been difficult due to the potential endogeneity issue that people who are more likely to engage in excessive drinking are also more likely to engage in IPV due to an unobserved third factor, people may misreport their alcohol abuse, and there might be reversed causality from IPV to alcohol abuse.

In this paper, we add to the existing literature on disentangling correlation from causality in the link between IPV and alcohol abuse by exploiting the unexpected and exogenous nature of $9 / 11$ and the timing of the data collection of Wave III of the AddHealth survey to identify the causal effect of alcohol abuse on IPV among young adult men. The strength of our IV is illustrated by the statistically significant results from our first stage estimation, and the richness of our data makes it possible to control for a wide range of confounding personal characteristics. Our 2SLS estimation results, which are robust to various specification checks, indicate that, contrary to the OLS results which support the common belief, alcohol abuse may not be the cause of IPV.

Finally, we realize that, as an important caveat, it cannot be completely ruled out that the insignificant 2SLS results could be partially attributed to the rather large 2SLS standard errors. However, we believe that the arguably exogenous nature of our IV and the consistent results from all the robustness checks at least indicate that policy makers, before investing public funds in certain anti-IPV programs, need to take into consideration the possibility that there might not be any causal effect of alcohol abuse on IPV. 
This research uses data from Add Health, a program project directed by Kathleen Mullan Harris and designed by J. Richard Udry, Peter S. Bearman, and Kathleen Mullan Harris at the University of North Carolina at Chapel Hill, and funded by grant P01-HD31921 from the Eunice Kennedy Shriver National Institute of Child Health and Human Development, with cooperative funding from 23 other federal agencies and foundations. Special acknowledgment is due Ronald R. Rindfuss and Barbara Entwisle for assistance in the original design. Information on how to obtain the Add Health data files is available on the Add Health website (http://www.cpc.unc.edu/addhealth). No direct support was received from grant P01-HD31921 for this analysis. 


\section{References}

Aizer, Anna. "Poverty, Violence, and Health The Impact of Domestic Violence During Pregnancy on Newborn Health." Journal of Human Resources 46, no. 3 (2011): 518-538.

Aslund, Olof, and Dan-Olof Rooth. "Shifts in attitudes and labor market discrimination: Swedish experiences after 9-11." Journal of Population Economics 18.4 (2005): 603-629.

Archer, John. "Sex differences in physically aggressive acts between heterosexual partners: A meta-analytic review." Aggression and Violent Behavior 7, no. 4 (2002): 313-351.

Averett, Susan L., and Yang Wang. "Identification of the effect of depression on risky sexual behavior: Exploiting a natural experiment." The American Economic Review 102, no. 3 (2012): 570-574.

Bush, Kristen, Daniel R. Kivlahan, Mary B. McDonell, Stephan D. Fihn, and Katharine A. Bradley. "The AUDIT alcohol consumption questions (AUDIT-C): an effective brief screening test for problem drinking." Archives of internal medicine 158, no. 16 (1998): 1789.

Campbell, Jacquelyn C. "Health consequences of intimate partner violence." Lancet 359, no. 9314 (2002): 1331-1336.

Caetano, Raul, John Schafer, and Carol B. Cunradi. "Alcohol-related intimate partner violence among white, black, and Hispanic couples in the United States." Alcohol Research and Health 25, no. 1 (2001): 58-65.

Caetano, Raul, Patrice AC Vaeth, and Suhasini Ramisetty-Mikler. "Intimate partner violence victim and perpetrator characteristics among couples in the United States." Journal of Family Violence 23, no. 6 (2008): 507-518.

CASA

2001, http://www.casacolumbia.org/templates/PressReleases.aspx?articleid=114\&zoneid=48.

Cameron, A. Colin, and Pravin K. Trivedi. Microeconometrics: methods and applications. Cambridge university press, 2005.

Card, David, and Gordon B. Dahl. "Family Violence and Football: The Effect of Unexpected Emotional Cues on Violent Behavior*." The Quarterly Journal of Economics 126, no. 1 (2011): 103-143.

Carpenter, Christopher, and Carlos Dobkin. "The drinking age, alcohol consumption, and crime." AEJ-Applied Microeconomics, forthcoming (2008).

CDC-National Center for Injury Prevention and Control. "Costs of Intimate Partner Violence Against Women in the United States.” Atlanta, Ga.: Centers for Disease Control and Prevention. (2003) 
Connor, Jennie, Ryan You, and Sally Casswell. "Alcohol-related harm to others: a survey of physical and sexual assault in New Zealand." Journal of the New Zealand Medical Association 122, no. 1303 (2009).

Djikanovic, Bosiljka, Henrica AFM Jansen, and Stanislava Otasevic. "Factors associated with intimate partner violence against women in Serbia: a cross-sectional study." Journal of epidemiology and community health 64, no. 8 (2010): 728-735.

Durrance, Christine Piette, Shelley Golden, Krista Perreira, and Philip Cook. "Taxing sin and saving lives: Can alcohol taxation reduce female homicides?." Social Science \& Medicine 73, no. 1 (2011): 169-176.

Farmer, Amy, and Jill Tiefenthaler. "An economic analysis of domestic violence." Review of Social Economy 55, no. 3 (1997): 337-358.

Garcia-Moreno, Claudia, Henrica AFM Jansen, Mary Ellsberg, Lori Heise, and Charlotte H. Watts. "Prevalence of intimate partner violence: findings from the WHO multi-country study on women's health and domestic violence." Lancet 368, no. 9543 (2006): 1260.

Gil-Gonzalez, Diana, Carmen Vives-Cases, Carlos Alvarez-Dardet, and Jaime Latour-Pérez. "Alcohol and intimate partner violence: do we have enough information to act?." The European Journal of Public Health 16, no. 3 (2006): 278-284.

Gomez, Anu Manchikanti. "Testing the cycle of violence hypothesis: Child abuse and adolescent dating violence as predictors of intimate partner violence in young adulthood." Youth \& Society 43, no. 1 (2011): 171-192.

Graham, Kathryn, Sharon Bernards, Sharon C. Wilsnack, and Gerhard Gmel. "Alcohol may not cause partner violence but it seems to make it worse: a cross national comparison of the relationship between alcohol and severity of partner violence." Journal of interpersonal violence 26, no. 8 (2011): 1503-1523.

Herttua, Kimmo. "The effects of the 2004 reduction in the price of alcohol on alcohol-related harm in Finland: A natural experiment based on register data." Finnish Yearbook of Population Research (2010).

Hidrobo, Melissa, and Lia Fernald. "Cash transfers and domestic violence." Journal of health economics 32, no. 1 (2013): 304-319.

Iyengar, Radha. "Does the certainty of arrest reduce domestic violence? Evidence from mandatory and recommended arrest laws." Journal of Public Economics 93.1 (2009): 85-98.

Johnson, Holly. "Contrasting views of the role of alcohol in cases of wife assault." Journal of interpersonal violence 16, no. 1 (2001): 54-72. 
Joseph, Stephen, William Yule, Ruth Williams, and Peter Hodgkinson. "Increased substance use in survivors of the Herald of Free Enterprise disaster." British Journal of Medical Psychology 66, no. 2 (2011): 185-191.

Kaura, Shelby A., and Craig M. Allen. "Dissatisfaction with relationship power and dating violence perpetration by men and women." Journal of Interpersonal Violence 19, no. 5 (2004): 576-588.

Kiss, Ligia, Lilia Blima Schraiber, Lori Heise, Cathy Zimmerman, Nelson Gouveia, and Charlotte Watts. "Gender-based violence and socioeconomic inequalities: Does living in more deprived neighbourhoods increase women's risk of intimate partner violence?." Social Science \& Medicine 74, no. 8 (2012): 1172-1179.

Livingston, Michael. "A longitudinal analysis of alcohol outlet density and domestic violence." Addiction 106, no. 5 (2011): 919-925.

Markowitz, Sara. "The price of alcohol, wife abuse, and husband abuse." Southern Economic Journal (2000): 279-303.

Markowitz, Sara, and Michael Grossman. "Alcohol regulation and domestic violence towards children." Contemporary Economic Policy 16, no. 3 (1998): 309-320.

Matthews, Kent, Jonathan Shepherd, and Vaseekaran Sivarajasingham. "Violence-related injury and the price of beer in England and Wales." Applied Economics 38, no. 6 (2006): 661-670.

National Center for Injury Prevention and Control. "Cost of Intimate Partner Violence Against Women in the United States.”. Atlanta, Ga. 2003

O'Farrell, Timothy J., Christopher M. Murphy, Sharon H. Stephan, William Fals-Stewart, and Marie Murphy. "Partner violence before and after couples-based alcoholism treatment for male alcoholic patients: the role of treatment involvement and abstinence." Journal of Consulting and Clinical Psychology 72, no. 2 (2004): 202.

The National Center on Addiction and Substance Abuse at Columbia University. 2001, "13 states and four major cities see increased demand for drug and alcohol treatment since september 11." http://www.casacolumbia.org/templates/PressReleases.aspx?articleid=114\&zoneid=48.

National Institute on Drug Abuse, National Institutes of Health "Stress, Depression and Drug Abuse: Fallout of September 11.

2003. http://www.medicinenet.com/script/main/art.asp?articlekey=24251

Peluso.P.2010. “FDNY Was Faced With Alcohol, Drug Abuse Problems Following 9/11.”

Pollak, Robert A. "An intergenerational model of domestic violence." Journal of Population Economics 17.2 (2004): 311-329. 
Powell, Lisa M., Christina U. Czart Ciecierski, Frank J. Chaloupka, and Henry Wechsler. "Binge drinking and violence among college students: Sensitivity to correlation in the unobservables." Chicago: University of Illinois (2002).

Roizen, Judith. "Issues in the epidemiology of alcohol and violence." Alcohol and interpersonal violence: Fostering multidisciplinary perspectives 1, no. 93 (1993): 3.

Ruiz-Pérez, Isabel, Juncal Plazaola-Castaño, and Carmen Vives-Cases. "Methodological issues in the study of violence against women." Journal of epidemiology and community health 61, no. Suppl 2 (2007): ii26-ii31.

Sabia, Joseph J. "Alcohol consumption and domestic violence against mothers." Journal of Mental Health Policy and Economics 7, no. 4 (2004): 191-205.

Smith, David W., Elaine H. Christiansen, Robert Vincent, and Neil E. Hann. "Population effects of the bombing of Oklahoma City." The Journal of the Oklahoma State Medical Association 92, no. 4 (1999): 193.

Straus, Murray A., Sherry L. Hamby, Sue Boney-McCoy, and David B. Sugarman. "The revised Conflict Tactics Scales (CTS2) development and preliminary psychometric data." Journal of family issues 17, no. 3 (1996): 283-316.

Tauchen, Helen V., Ann Dryden Witte, and Sharon K. Long. "Domestic violence: A non-random affair." International Economic Review, Vol. 32, No. 2 (1991): pp. 491-511.

Thompson, Robert S., Amy E. Bonomi, Melissa Anderson, Robert J. Reid, Jane A. Dimer, David Carrell, and Frederick P. Rivara. "Intimate partner violence: prevalence, types, and chronicity in adult women." American journal of preventive medicine (2006).

Tjaden, Patricia Godeke, and Nancy Thoennes. "Extent, nature, and consequences of intimate partner violence: Findings from the National Violence Against Women Survey.” Washington, DC: National Institute of Justice, 2000.

Tumwesigye, Nazarius M., Grace B. Kyomuhendo, Thomas K. Greenfield, and Rhoda K. Wanyenze. "Problem drinking and physical intimate partner violence against women: evidence from a national survey in Uganda." BMC Public Health 12, no. 1 (2012): 399.

United Nations., 1995. Fourth World Conference on

Women. http://www.un.org/womenwatch/daw/beijing/pdf/Beijing\%20full\%20report\%20E.pdf. (Accessed July 5, 2011).

Vlahov, David, Sandro Galea, Heidi Resnick, Jennifer Ahern, Joseph A. Boscarino, Michael Bucuvalas, Joel Gold, and Dean Kilpatrick. "Increased use of cigarettes, alcohol, and marijuana among Manhattan, New York, residents after the September 11th terrorist attacks." American Journal of Epidemiology 155, no. 11 (2002): 988-996. 
Vlahov, David, Sandro Galea, Jennifer Ahern, Heidi Resnick, Joseph A. Boscarino, Joel Gold, Michael Bucuvalas, and Dean Kilpatrick. "Consumption of cigarettes, alcohol, and marijuana among New York City residents six months after the September 11 terrorist attacks." The American journal of drug and alcohol abuse 30, no. 2 (2004): 385-407.

Wang, Yang, and Muzhe Yang. "Crisis-Induced Depression, Physical Activity and Dietary Intake among Young Adults: Evidence from the 9/11 Terrorist Attacks." Economics \& Human Biology (2012).

White, Helene Raskin, and Ping-Hsin Chen. "Problem drinking and intimate partner violence." Journal of Studies on Alcohol and Drugs 63, no. 2 (2002): 205.

World Health Organization. WHO Multi-country Study on Women's Health and Domestic Violence Against Women: Initial Results on Prevalence, Health Outcomes and Women's Responses. World Health Organization, 2005. 
Figure 1A. Distribution of Interviews for AddHealth Wave III.

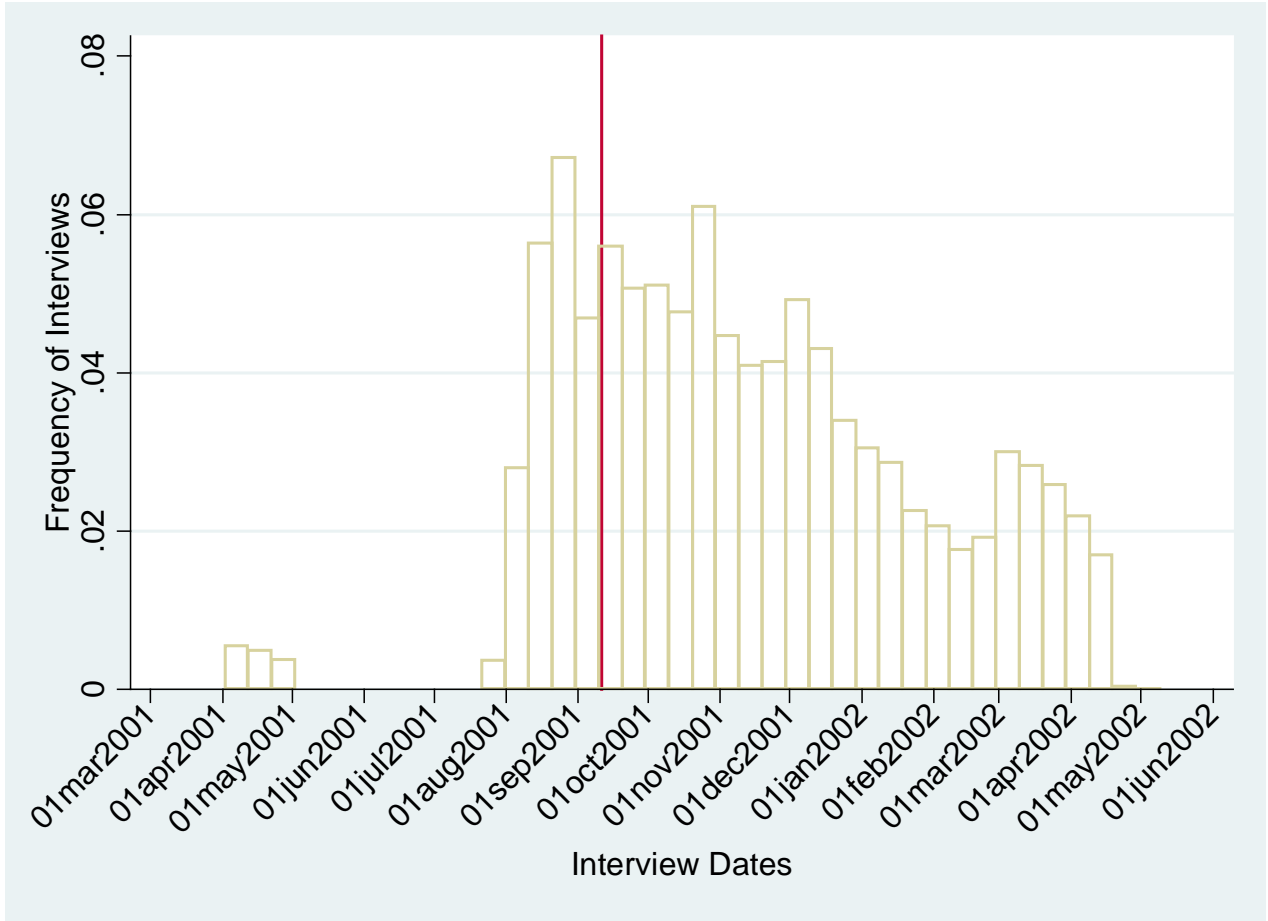

Figure 1B. Distribution of Interviews for the Analysis Sample.

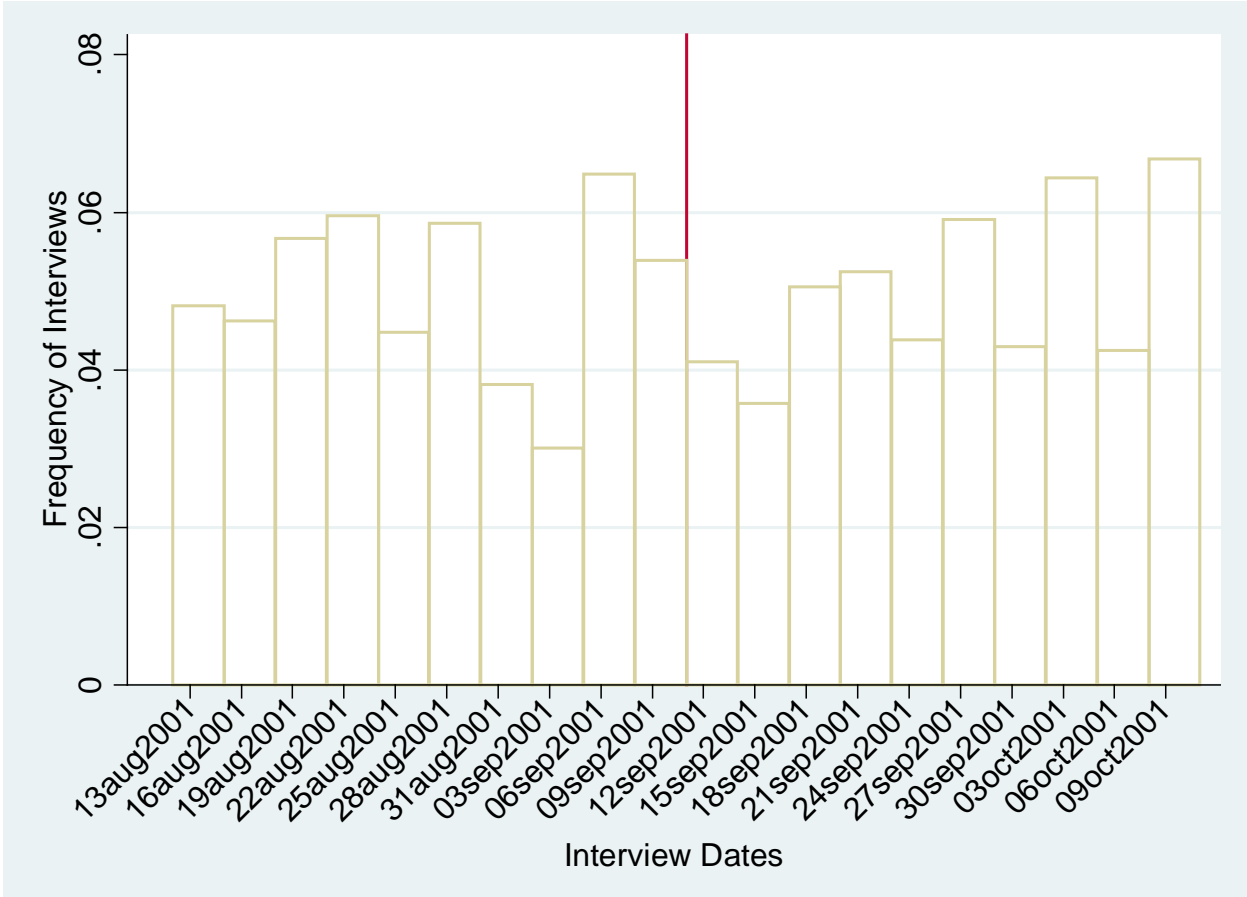


Figure 2. Distributions of Weekly Average of Times Engaging in Heavy Drinking.

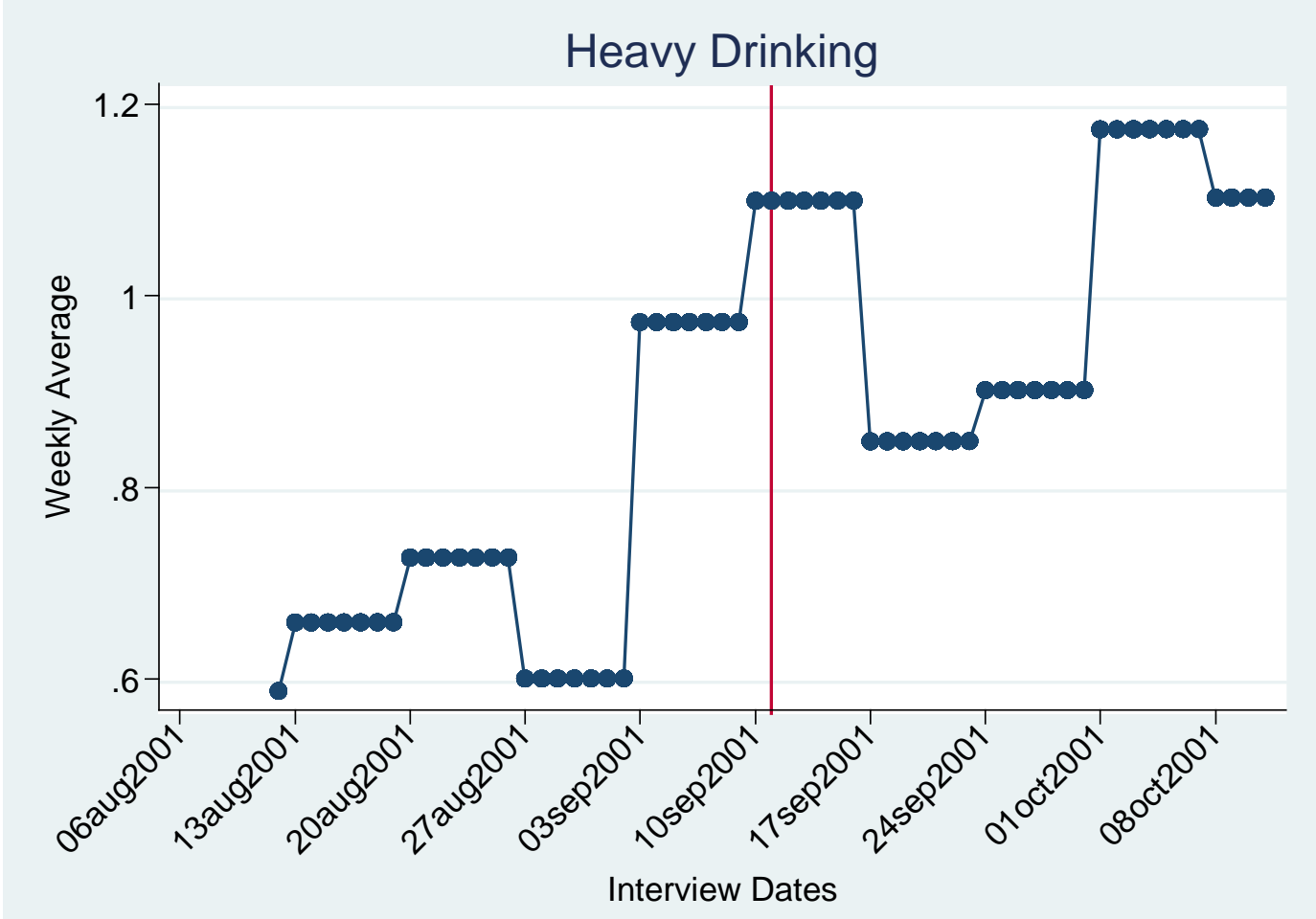


Figure 3. Distributions of Weekly Averages of the Two Outcome Variables.
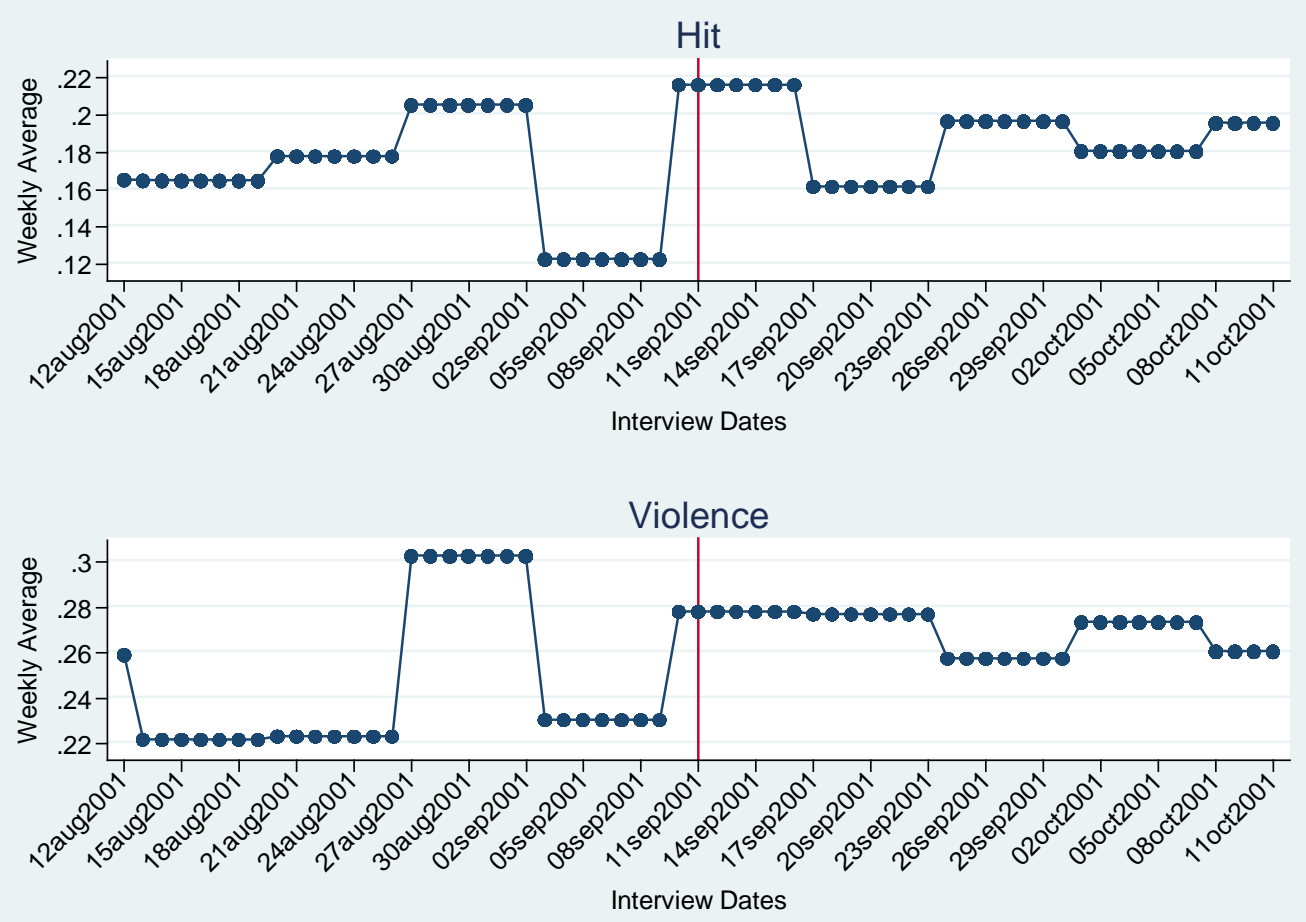
Table 1. Summary Statistics

\begin{tabular}{|c|c|c|c|c|c|}
\hline VARIABLES & Obs & Mean & Std. Dev. & Min & Max \\
\hline Alcohol Abuse & 2100 & 1.344 & 2.361 & $\overline{0}$ & 14 \\
\hline Interviewed after 9/11 & 2100 & 0.501 & 0.500 & 0 & 1 \\
\hline $\begin{array}{l}\text { \# of Days between } \\
\text { interview and } 9 / 11\end{array}$ & 2100 & 0.156 & 17.802 & -30 & 30 \\
\hline Hit Partner & 2100 & 0.171 & 0.377 & 0 & 1 \\
\hline Violent Towards Partner & 2088 & 0.248 & 0.432 & 0 & 1 \\
\hline Age & 2100 & 21.762 & 1.752 & 18 & 27 \\
\hline Age 21 or above & 2100 & 0.734 & 0.442 & 0 & 1 \\
\hline White & 2100 & 0.724 & 0.447 & 0 & 1 \\
\hline Hispanic & 2100 & 0.170 & 0.376 & 0 & 1 \\
\hline Years of Education & 2100 & 13.085 & 1.862 & 6 & 20 \\
\hline Ever Married & 2100 & 0.151 & 0.359 & 0 & 1 \\
\hline First Income Quintile & 2100 & 0.124 & 0.329 & 0 & 1 \\
\hline Second Income Quintile & 2100 & 0.185 & 0.388 & 0 & 1 \\
\hline Third Income Quintile & 2100 & 0.187 & 0.390 & 0 & 1 \\
\hline Fourth Income Quintile & 2100 & 0.230 & 0.421 & 0 & 1 \\
\hline Fifth Income Quintile & 2100 & 0.230 & 0.421 & 0 & 1 \\
\hline Income Missing & 2100 & 0.044 & 0.206 & 0 & 1 \\
\hline Dating Problems & 1980 & 0.112 & 0.315 & 0 & 1 \\
\hline Regret due to Alcohol & 1981 & 0.150 & 0.357 & 0 & 1 \\
\hline Depress & 2098 & 0.276 & 0.586 & 0 & 3 \\
\hline Stress & 2098 & 0.035 & 0.183 & 0 & 1 \\
\hline Ever Smoked Cigarettes & 2092 & 0.410 & 0.492 & 0 & 1 \\
\hline Marijuana Last Year & 2052 & 0.504 & 0.500 & 0 & 1 \\
\hline Index of Risk Taking & 1994 & 16.945 & 5.839 & 6 & 30 \\
\hline Ever Gamble & 2093 & 0.651 & 0.477 & 0 & 1 \\
\hline Played Lottery & 2095 & 0.650 & 0.477 & 0 & 1 \\
\hline
\end{tabular}

*Alcohol abuse is defined as the number of days that an individual had five or more drinks on a single occasion. 
Table 2A. Means by the Instrument Variable: Number of Days between Interview and 9/11.

\begin{tabular}{|c|c|c|c|c|c|c|c|c|c|c|c|c|}
\hline VARIABLES & $\begin{array}{l}\text { (1) } \\
\text { Age }\end{array}$ & $\begin{array}{c}\text { (2) } \\
21 \text { or above }\end{array}$ & $\begin{array}{c}(3) \\
\text { Hispanic }\end{array}$ & $\begin{array}{c}(4) \\
\text { White }\end{array}$ & $\begin{array}{c}\text { (5) } \\
\text { Years of } \\
\text { Education }\end{array}$ & $\begin{array}{c}6) \\
\text { Ever } \\
\text { Married }\end{array}$ & $\begin{array}{c}(7) \\
\text { First Income } \\
\text { Quintile }\end{array}$ & $\begin{array}{c}\text { (8) } \\
\text { Second } \\
\text { Income } \\
\text { Quintile } \\
\end{array}$ & $\begin{array}{c}\text { (9) } \\
\text { Third } \\
\text { Income } \\
\text { Quintile } \\
\end{array}$ & $\begin{array}{c}\text { (10) } \\
\text { Fourth } \\
\text { Income } \\
\text { Quintile } \\
\end{array}$ & $\begin{array}{c}\text { (11) } \\
\text { Fifth } \\
\text { Income } \\
\text { Quintile } \\
\end{array}$ & $\begin{array}{c}(12) \\
\text { Income } \\
\text { Missing }\end{array}$ \\
\hline IV & $\begin{array}{c}0.001 \\
(0.002)\end{array}$ & $\begin{array}{l}-0.000 \\
(0.001)\end{array}$ & $\begin{array}{c}0.000 \\
(0.001)\end{array}$ & $\begin{array}{c}0.000 \\
(0.001)\end{array}$ & $\begin{array}{c}-0.009 * * * \\
(0.002)\end{array}$ & $\begin{array}{c}-0.0005 \\
(0.0004)\end{array}$ & $\begin{array}{c}0.002^{* * * *} \\
(0.0004)\end{array}$ & $\begin{array}{c}0.0002 \\
(0.0005)\end{array}$ & $\begin{array}{c}-0.001 * * * \\
(0.0004)\end{array}$ & $\begin{array}{l}-0.0004 \\
(0.001)\end{array}$ & $\begin{array}{l}0.0002 \\
(0.001)\end{array}$ & $\begin{array}{c}-0.0002 \\
(0.0002)\end{array}$ \\
\hline Constant & $\begin{array}{c}21.762 * * * \\
(0.038)\end{array}$ & $\begin{array}{c}0.734 * * * \\
(0.010)\end{array}$ & $\begin{array}{c}0.170^{* * *} \\
(0.008)\end{array}$ & $\begin{array}{c}0.724 * * * \\
(0.010)\end{array}$ & $\begin{array}{c}13.086^{* * * *} \\
(0.040)\end{array}$ & $\begin{array}{c}0.152^{* * *} \\
(0.008)\end{array}$ & $\begin{array}{c}0.124^{* * *} \\
(0.007)\end{array}$ & $\begin{array}{c}0.185^{* * *} \\
(0.008)\end{array}$ & $\begin{array}{c}0.187 * * * \\
(0.009)\end{array}$ & $\begin{array}{c}0.231^{* * *} \\
(0.009)\end{array}$ & $\begin{array}{c}0.229 * * * \\
(0.009)\end{array}$ & $\begin{array}{c}0.044 * * * \\
(0.004)\end{array}$ \\
\hline $\begin{array}{l}\text { Observations } \\
\text { R-squared }\end{array}$ & $\begin{array}{l}2,100 \\
0.000\end{array}$ & $\begin{array}{l}2100 \\
0.000\end{array}$ & $\begin{array}{l}2,100 \\
0.000\end{array}$ & $\begin{array}{l}2,100 \\
0.000\end{array}$ & $\begin{array}{l}2,100 \\
0.005\end{array}$ & $\begin{array}{l}2,100 \\
0.000\end{array}$ & $\begin{array}{l}2,100 \\
0.011\end{array}$ & $\begin{array}{l}2,100 \\
0.000\end{array}$ & $\begin{array}{l}2,100 \\
0.003\end{array}$ & $\begin{array}{l}2,100 \\
0.000\end{array}$ & $\begin{array}{l}2,100 \\
0.000\end{array}$ & $\begin{array}{l}2,100 \\
0.000\end{array}$ \\
\hline
\end{tabular}

Coefficients are from a regression of each independent variable on a continuous variable measuring the number of days between interview and 9/11, thus each column is a separate

regression. Robust standard errors in parentheses. $* * * \mathrm{p}<0.01, * * \mathrm{p}<0.05$ 
Table 2B. Means by the Instrument Variable: Number of Days between Interview and 9/11.

\begin{tabular}{|c|c|c|c|c|c|c|c|c|c|c|}
\hline VARIABLES & $\begin{array}{c}(1) \\
\text { Dating } \\
\text { Problems }\end{array}$ & $\begin{array}{c}\text { (2) } \\
\text { Regret due to } \\
\text { Alcohol }\end{array}$ & $\begin{array}{c}(3) \\
\text { Depress }\end{array}$ & $\begin{array}{c}(4) \\
\text { Stress }\end{array}$ & $\begin{array}{c}(5) \\
\text { Ever } \\
\text { Smoked } \\
\text { Cigarettes } \\
\end{array}$ & $\begin{array}{c}(6) \\
\text { Marijuana } \\
\text { Last Year }\end{array}$ & $\begin{array}{c}(7) \\
\text { Index of } \\
\text { Risk } \\
\text { Taking } \\
\end{array}$ & $\begin{array}{c}(8) \\
\text { Ever } \\
\text { Gamble }\end{array}$ & $\begin{array}{c}9) \\
\text { Played Lottery }\end{array}$ & $\begin{array}{c}(10) \\
\text { Heavy Drinking }\end{array}$ \\
\hline IV & $\begin{array}{l}-0.0002 \\
(0.0004)\end{array}$ & $\begin{array}{l}-0.0001 \\
(0.0004)\end{array}$ & $\begin{array}{c}0.001 \\
(0.001)\end{array}$ & $\begin{array}{l}-0.0001 \\
(0.0002)\end{array}$ & $\begin{array}{c}0.002^{* * *} \\
(0.001)\end{array}$ & $\begin{array}{c}0.002 * * * \\
(0.001)\end{array}$ & $\begin{array}{c}0.021^{* * * *} \\
(0.007)\end{array}$ & $\begin{array}{l}-0.0003 \\
(0.001)\end{array}$ & $\begin{array}{l}0.0002 \\
(0.001)\end{array}$ & $\begin{array}{c}0.014^{* * *} \\
(0.003)\end{array}$ \\
\hline Constant & $\begin{array}{c}0.112 * * * \\
(0.007)\end{array}$ & $\begin{array}{c}0.150^{* * *} \\
(0.008)\end{array}$ & $\begin{array}{c}0.276 * * * \\
(0.013)\end{array}$ & $\begin{array}{c}0.035^{* * *} \\
(0.004)\end{array}$ & $\begin{array}{c}0.410^{* * *} \\
(0.011)\end{array}$ & $\begin{array}{c}0.504^{* * *} \\
(0.011)\end{array}$ & $\begin{array}{c}16.937 * * * \\
(0.131)\end{array}$ & $\begin{array}{c}0.651^{* * *} \\
(0.010)\end{array}$ & $\begin{array}{c}0.650 * * * \\
(0.010)\end{array}$ & $\begin{array}{c}1.342 * * * \\
(0.051)\end{array}$ \\
\hline $\begin{array}{l}\text { Observations } \\
\text { R-squared }\end{array}$ & $\begin{array}{l}1,980 \\
0.000\end{array}$ & $\begin{array}{l}1,981 \\
0.000\end{array}$ & $\begin{array}{l}2,098 \\
0.002\end{array}$ & $\begin{array}{l}2,100 \\
0.000\end{array}$ & $\begin{array}{l}2,092 \\
0.006\end{array}$ & $\begin{array}{l}2,052 \\
0.005\end{array}$ & $\begin{array}{l}1,994 \\
0.004\end{array}$ & $\begin{array}{l}2,093 \\
0.000\end{array}$ & $\begin{array}{l}2,095 \\
0.000\end{array}$ & $\begin{array}{l}2,100 \\
0.011\end{array}$ \\
\hline
\end{tabular}

Coefficients are from a regression of each independent variable on a continuous variable measuring the number of days between interview and 9/11, thus each column is a separate

regression. Robust standard errors in parentheses. ${ }^{* * *} \mathrm{p}<0.01, * * \mathrm{p}<0.05$ 
Table 3. OLS Results.

\begin{tabular}{|c|c|c|c|c|c|c|c|c|}
\hline VARIABLES & $\begin{array}{c}\text { (1) } \\
\text { Hit Partner }\end{array}$ & $\begin{array}{c}(2) \\
\text { Hit Partner }\end{array}$ & $\begin{array}{c}\text { (3) } \\
\text { Hit Partner }\end{array}$ & $\begin{array}{c}(4) \\
\text { Hit Partner }\end{array}$ & $\begin{array}{c}5) \\
\text { Violent } \\
\text { towards } \\
\text { Partner } \\
\end{array}$ & $\begin{array}{c}(6) \\
\text { Violent } \\
\text { towards } \\
\text { Partner } \\
\end{array}$ & $\begin{array}{c}(7) \\
\text { Violent } \\
\text { towards } \\
\text { Partner } \\
\end{array}$ & $\begin{array}{c}(8) \\
\text { Violent } \\
\text { towards } \\
\text { Partner } \\
\end{array}$ \\
\hline Alcohol Abuse ${ }^{*}$ & $\begin{array}{c}0.013 * * * \\
(0.004)\end{array}$ & $\begin{array}{c}0.013 * * * \\
(0.004)\end{array}$ & $\begin{array}{c}0.014 * * * \\
(0.004)\end{array}$ & $\begin{array}{c}0.013 * * * \\
(0.005)\end{array}$ & $\begin{array}{c}0.013 * * * \\
(0.004)\end{array}$ & $\begin{array}{c}0.012 * * * \\
(0.004)\end{array}$ & $\begin{array}{c}0.013^{* * *} \\
(0.005)\end{array}$ & $\begin{array}{c}0.014 * * * \\
(0.005)\end{array}$ \\
\hline Age & & $\begin{array}{l}-0.010 \\
(0.007)\end{array}$ & $\begin{array}{l}-0.013 \\
(0.008)\end{array}$ & $\begin{array}{c}-0.011 \\
(0.008)\end{array}$ & & $\begin{array}{c}0.003 \\
(0.009)\end{array}$ & $\begin{array}{c}0.002 \\
(0.009)\end{array}$ & $\begin{array}{l}-0.003 \\
(0.009)\end{array}$ \\
\hline Age 21 or Older & & $\begin{array}{c}0.015 \\
(0.030)\end{array}$ & $\begin{array}{c}0.039 \\
(0.030)\end{array}$ & $\begin{array}{c}0.040 \\
(0.032)\end{array}$ & & $\begin{array}{l}-0.030 \\
(0.035)\end{array}$ & $\begin{array}{l}-0.000 \\
(0.036)\end{array}$ & $\begin{array}{c}0.025 \\
(0.037)\end{array}$ \\
\hline White & & $\begin{array}{c}0.045^{* *} \\
(0.018)\end{array}$ & $\begin{array}{c}0.025 \\
(0.018)\end{array}$ & $\begin{array}{c}0.019 \\
(0.020)\end{array}$ & & $\begin{array}{c}0.050 * * \\
(0.021)\end{array}$ & $\begin{array}{c}0.042 * * \\
(0.021)\end{array}$ & $\begin{array}{c}0.039 \\
(0.023)\end{array}$ \\
\hline Hispanic & & $\begin{array}{l}-0.013 \\
(0.022)\end{array}$ & $\begin{array}{c}0.002 \\
(0.022)\end{array}$ & $\begin{array}{c}0.001 \\
(0.024)\end{array}$ & & $\begin{array}{l}-0.030 \\
(0.025)\end{array}$ & $\begin{array}{l}-0.024 \\
(0.025)\end{array}$ & $\begin{array}{l}-0.038 \\
(0.026)\end{array}$ \\
\hline Years of Education & & $\begin{array}{l}-0.001 \\
(0.005)\end{array}$ & $\begin{array}{c}0.002 \\
(0.005)\end{array}$ & $\begin{array}{c}0.003 \\
(0.005)\end{array}$ & & $\begin{array}{l}-0.001 \\
(0.005)\end{array}$ & $\begin{array}{c}0.004 \\
(0.005)\end{array}$ & $\begin{array}{c}0.007 \\
(0.006)\end{array}$ \\
\hline Ever Married & & $\begin{array}{c}0.035 \\
(0.025)\end{array}$ & $\begin{array}{c}0.033 \\
(0.025)\end{array}$ & $\begin{array}{c}0.036 \\
(0.026)\end{array}$ & & $\begin{array}{l}-0.010 \\
(0.028)\end{array}$ & $\begin{array}{l}-0.030 \\
(0.028)\end{array}$ & $\begin{array}{l}-0.025 \\
(0.030)\end{array}$ \\
\hline First Income Quintile & & $\begin{array}{l}-0.036 \\
(0.029)\end{array}$ & $\begin{array}{l}-0.034 \\
(0.029)\end{array}$ & $\begin{array}{l}-0.024 \\
(0.031)\end{array}$ & & $\begin{array}{l}-0.010 \\
(0.035)\end{array}$ & $\begin{array}{l}-0.001 \\
(0.035)\end{array}$ & $\begin{array}{c}-0.003 \\
(0.037)\end{array}$ \\
\hline $\begin{array}{l}\text { Second Income } \\
\text { Quintile }\end{array}$ & & 0.005 & 0.003 & -0.005 & & 0.015 & -0.000 & -0.036 \\
\hline Third Income Quintile & & $\begin{array}{l}(0.027) \\
-0.018 \\
(0.027)\end{array}$ & $\begin{array}{l}(0.028) \\
-0.028 \\
(0.028)\end{array}$ & $\begin{array}{l}(0.029) \\
-0.014 \\
(0.029)\end{array}$ & & $\begin{array}{l}(0.032) \\
-0.005 \\
(0.031)\end{array}$ & $\begin{array}{l}(0.032) \\
-0.007 \\
(0.032)\end{array}$ & $\begin{array}{l}(0.033) \\
-0.008 \\
(0.033)\end{array}$ \\
\hline $\begin{array}{l}\text { Fourth Income } \\
\text { Quintile }\end{array}$ & & -0.024 & -0.029 & -0.026 & & -0.018 & -0.024 & -0.037 \\
\hline Income Missing & & $\begin{array}{c}(0.025) \\
0.060 \\
(0.047)\end{array}$ & $\begin{array}{c}(0.025) \\
0.057 \\
(0.049)\end{array}$ & $\begin{array}{c}(0.026) \\
0.075 \\
(0.052)\end{array}$ & & $\begin{array}{c}(0.028) \\
0.087 \\
(0.052)\end{array}$ & $\begin{array}{c}(0.029) \\
0.090 \\
(0.054)\end{array}$ & $\begin{array}{c}(0.030) \\
0.076 \\
(0.059)\end{array}$ \\
\hline Dating Problems & & & $\begin{array}{l}0.048 \\
(0.033)\end{array}$ & $\begin{array}{c}0.057 \\
(0.034)\end{array}$ & & & $\begin{array}{c}0.116^{* * * *} \\
(0.038)\end{array}$ & $\begin{array}{c}0.117 * * * \\
(0.040)\end{array}$ \\
\hline Regret due to Alcohol & & & $\begin{array}{c}0.054 \\
(0.029)\end{array}$ & $\begin{array}{c}0.045 \\
(0.030)\end{array}$ & & & $\begin{array}{c}0.067 * * \\
(0.033)\end{array}$ & $\begin{array}{c}0.062 \\
(0.034)\end{array}$ \\
\hline Depress & & & $\begin{array}{c}0.021 \\
(0.015)\end{array}$ & $\begin{array}{c}0.023 \\
(0.015)\end{array}$ & & & $\begin{array}{c}0.012 \\
(0.017)\end{array}$ & $\begin{array}{c}0.015 \\
(0.018)\end{array}$ \\
\hline Stress & & & $\begin{array}{c}0.055 \\
(0.054)\end{array}$ & $\begin{array}{c}0.008 \\
(0.052)\end{array}$ & & & $\begin{array}{c}0.082 \\
(0.062)\end{array}$ & $\begin{array}{c}0.081 \\
(0.064)\end{array}$ \\
\hline Ever Smoked & & & & $\begin{array}{l}-0.014 \\
(0.020)\end{array}$ & & & & $\begin{array}{l}-0.020 \\
(0.023)\end{array}$ \\
\hline Marijuana Last Year & & & & $\begin{array}{c}0.015 \\
(0.020)\end{array}$ & & & & $\begin{array}{c}0.020 \\
(0.022)\end{array}$ \\
\hline Index of Risk Taking & & & & $\begin{array}{l}-0.000 \\
(0.002)\end{array}$ & & & & $\begin{array}{c}0.000 \\
(0.002)\end{array}$ \\
\hline Ever Gamble & & & & $\begin{array}{c}0.023 \\
(0.020)\end{array}$ & & & & $\begin{array}{c}0.015 \\
(0.023)\end{array}$ \\
\hline Play Lottery & & & & $\begin{array}{c}0.007 \\
(0.021)\end{array}$ & & & & $\begin{array}{c}-0.049 * * \\
(0.024)\end{array}$ \\
\hline Constant & $\begin{array}{l}0.153^{* * *} \\
(0.009)\end{array}$ & $\begin{array}{r}0.335^{* *} \\
(0.161)\end{array}$ & $\begin{array}{c}0.341^{* *} \\
(0.164)\end{array}$ & $\begin{array}{c}0.280 \\
(0.179)\end{array}$ & $\begin{array}{l}0.233^{* * *} \\
(0.011)\end{array}$ & $\begin{array}{c}0.178 \\
(0.190)\end{array}$ & $\begin{array}{c}0.096 \\
(0.195)\end{array}$ & $\begin{array}{c}0.171 \\
(0.208)\end{array}$ \\
\hline Observations & 2,100 & 2,100 & 1,978 & 1,847 & 2,098 & 2,098 & 1,977 & 1,846 \\
\hline R-squared & 0.007 & 0.014 & 0.024 & 0.023 & 0.005 & 0.011 & 0.029 & 0.032 \\
\hline
\end{tabular}

*Alcohol abuse is defined as the number of days that an individual had five or more drinks on a single occasion. Robust standard errors in parentheses. $* * * \mathrm{p}<0.01, * * \mathrm{p}<0.05$ 
Tabe 4. 2SLS Results. First Stage. Dependent Variable is Number of Times with More Than 5 Drinks on one Occasion in Past Two Weeks.

\begin{tabular}{|c|c|c|c|c|c|c|c|c|}
\hline VARIABLES & $\begin{array}{c}\text { (1) } \\
\text { Alcohol } \\
\text { Abuse } \\
\end{array}$ & $\begin{array}{c}(2) \\
\text { Alcohol } \\
\text { Abuse } \\
\end{array}$ & $\begin{array}{c}(3) \\
\text { Alcohol } \\
\text { Abuse } \\
\end{array}$ & $\begin{array}{c}(4) \\
\text { Alcohol } \\
\text { Abuse } \\
\end{array}$ & $\begin{array}{c}(5) \\
\text { Alcohol } \\
\text { Abuse } \\
\end{array}$ & $\begin{array}{c}(6) \\
\text { Alcohol } \\
\text { Abuse } \\
\end{array}$ & $\begin{array}{c}(7) \\
\text { Alcohol } \\
\text { Abuse } \\
\end{array}$ & $\begin{array}{c}(8) \\
\text { Alcohol } \\
\text { Abuse } \\
\end{array}$ \\
\hline IV (9/11 days) & $\begin{array}{c}0.014 * * * \\
(0.003)\end{array}$ & $\begin{array}{c}0.013^{* * *} \\
(0.003)\end{array}$ & $\begin{array}{c}0.014 * * * \\
(0.003)\end{array}$ & $\begin{array}{c}0.011^{* * *} \\
(0.003)\end{array}$ & $\begin{array}{c}0.013 * * * \\
(0.003)\end{array}$ & $\begin{array}{c}0.013 * * * \\
(0.003)\end{array}$ & $\begin{array}{c}0.013^{* * *} \\
(0.003)\end{array}$ & $\begin{array}{c}0.011^{* * *} \\
(0.003)\end{array}$ \\
\hline Age & & $\begin{array}{l}-0.087 \\
(0.049)\end{array}$ & $\begin{array}{l}-0.082 \\
(0.051)\end{array}$ & $\begin{array}{l}-0.039 \\
(0.050)\end{array}$ & & $\begin{array}{l}-0.093 \\
(0.049)\end{array}$ & $\begin{array}{l}-0.091 \\
(0.051)\end{array}$ & $\begin{array}{l}-0.051 \\
(0.049)\end{array}$ \\
\hline Age 21 or Older & & $\begin{array}{c}0.338 \\
(0.194)\end{array}$ & $\begin{array}{c}0.251 \\
(0.202)\end{array}$ & $\begin{array}{c}0.092 \\
(0.194)\end{array}$ & & $\begin{array}{c}0.363 \\
(0.193)\end{array}$ & $\begin{array}{l}0.285 \\
(0.201)\end{array}$ & $\begin{array}{c}0.136 \\
(0.192)\end{array}$ \\
\hline White & & $\begin{array}{c}0.464^{* * * *} \\
(0.116)\end{array}$ & $\begin{array}{c}0.517 * * * \\
(0.119)\end{array}$ & $\begin{array}{c}0.401 * * * \\
(0.115)\end{array}$ & & $\begin{array}{c}0.454 * * * \\
(0.114)\end{array}$ & $\begin{array}{c}0.508^{* * *} \\
(0.118)\end{array}$ & $\begin{array}{c}0.397^{* * *} \\
(0.114)\end{array}$ \\
\hline Hispanic & & $\begin{array}{c}-0.279 * * \\
(0.121)\end{array}$ & $\begin{array}{c}-0.274^{* *} \\
(0.124)\end{array}$ & $\begin{array}{l}-0.095 \\
(0.122)\end{array}$ & & $\begin{array}{c}-0.268 * * \\
(0.120)\end{array}$ & $\begin{array}{c}-0.263 * * \\
(0.123)\end{array}$ & $\begin{array}{l}-0.085 \\
(0.122)\end{array}$ \\
\hline $\begin{array}{l}\text { Years of } \\
\text { Education }\end{array}$ & & $\begin{array}{l}-0.043 \\
(0.027)\end{array}$ & $\begin{array}{l}-0.035 \\
(0.027)\end{array}$ & $\begin{array}{c}0.013 \\
(0.026)\end{array}$ & & $\begin{array}{l}-0.041 \\
(0.027)\end{array}$ & $\begin{array}{l}-0.033 \\
(0.027)\end{array}$ & $\begin{array}{c}0.014 \\
(0.026)\end{array}$ \\
\hline Ever Married & & $\begin{array}{c}-0.629 * * * \\
(0.131)\end{array}$ & $\begin{array}{c}-0.580 * * * \\
(0.139)\end{array}$ & $\begin{array}{c}-0.456 * * * \\
(0.136)\end{array}$ & & $\begin{array}{c}-0.600^{* * * *} \\
(0.131)\end{array}$ & $\begin{array}{c}-0.556^{* * * *} \\
(0.138)\end{array}$ & $\begin{array}{c}-0.432^{* * *} \\
(0.135)\end{array}$ \\
\hline $\begin{array}{l}\text { First Income } \\
\text { Ouintile }\end{array}$ & & $\begin{array}{c}-0.419 * * \\
(0.203)\end{array}$ & $\begin{array}{c}-0.498 * * \\
(0.208)\end{array}$ & $\begin{array}{l}-0.311 \\
(0.211)\end{array}$ & & $\begin{array}{c}-0.449 * * \\
(0.198)\end{array}$ & $\begin{array}{c}-0.529 * * * \\
(0.203)\end{array}$ & $\begin{array}{l}-0.344 \\
(0.207)\end{array}$ \\
\hline Second Income & & -0.324 & $-0.366^{* *}$ & -0.187 & & -0.330 & $-0.372 * *$ & -0.196 \\
\hline Quintile & & $(0.176)$ & $(0.180)$ & $(0.180)$ & & $(0.176)$ & $(0.179)$ & $(0.179)$ \\
\hline Third Income & & $-0.384 * *$ & $-0.453 * *$ & $-0.437 * *$ & & $-0.384 * *$ & $-0.451 * *$ & $-0.435^{* *}$ \\
\hline Quintile & & $(0.168)$ & $(0.177)$ & $(0.170)$ & & $(0.167)$ & $(0.176)$ & $(0.169)$ \\
\hline Fourth Income & & -0.133 & -0.141 & -0.249 & & -0.120 & -0.128 & -0.234 \\
\hline Quintile & & $(0.152)$ & $(0.158)$ & $(0.155)$ & & $(0.152)$ & (0.158) & $(0.155)$ \\
\hline Income Missing & & -0.355 & -0.274 & 0.160 & & -0.364 & -0.289 & 0.158 \\
\hline Dating Problems & & $(0.258)$ & $\begin{array}{l}(0.274) \\
-0.037 \\
(0.180)\end{array}$ & $\begin{array}{l}(0.280) \\
-0.044 \\
(0.174)\end{array}$ & & $(0.256)$ & $\begin{array}{c}(0.272) \\
-0.032 \\
(0.180)\end{array}$ & $\begin{array}{l}(0.280) \\
-0.028 \\
(0.175)\end{array}$ \\
\hline Regret due to Alcohol & & & 0.250 & 0.269 & & & 0.256 & 0.277 \\
\hline Depress & & & $\begin{array}{c}(0.162) \\
0.098 \\
(0.085)\end{array}$ & $\begin{array}{l}(0.156) \\
-0.053 \\
(0.082)\end{array}$ & & & $\begin{array}{c}(0.161) \\
0.074 \\
(0.083)\end{array}$ & $\begin{array}{l}(0.156) \\
-0.073 \\
(0.081)\end{array}$ \\
\hline Stress & & & $\begin{array}{c}0.048 \\
(0.352)\end{array}$ & $\begin{array}{l}-0.031 \\
(0.350)\end{array}$ & & & $\begin{array}{c}0.076 \\
(0.351)\end{array}$ & $\begin{array}{l}-0.003 \\
(0.350)\end{array}$ \\
\hline Ever Smoked & & & & $\begin{array}{c}0.695^{* * *} \\
(0.125)\end{array}$ & & & & $\begin{array}{c}0.695^{* * *} \\
(0.124)\end{array}$ \\
\hline Marijuana Last Year & & & & $\begin{array}{c}0.605^{* * * *} \\
(0.109)\end{array}$ & & & & $\begin{array}{c}0.602^{* * *} \\
(0.109)\end{array}$ \\
\hline Index of Risk Taking & & & & $\begin{array}{c}0.065^{* * * *} \\
(0.009)\end{array}$ & & & & $\begin{array}{c}0.062^{* * *} \\
(0.009)\end{array}$ \\
\hline Ever Gamble & & & & $\begin{array}{c}0.316^{* * *} \\
(0.114)\end{array}$ & & & & $\begin{array}{c}0.318^{* * *} \\
(0.114)\end{array}$ \\
\hline Play Lottery & & & & $\begin{array}{c}0.239 * * \\
(0.116)\end{array}$ & & & & $\begin{array}{c}0.224 \\
(0.115)\end{array}$ \\
\hline Constant & $\begin{array}{c}1.342^{* * *} \\
(0.051)\end{array}$ & $\begin{array}{c}3.577^{* * *} \\
(1.040)\end{array}$ & $\begin{array}{c}3.368 * * * \\
(1.088)\end{array}$ & $\begin{array}{l}-0.076 \\
(1.092)\end{array}$ & $\begin{array}{c}1.332 * * * \\
(0.051)\end{array}$ & $\begin{array}{c}3.669 * * * \\
(1.037)\end{array}$ & $\begin{array}{c}3.514 * * * \\
(1.085)\end{array}$ & $\begin{array}{c}0.164 \\
(1.085)\end{array}$ \\
\hline Observations & 2,100 & 2,100 & 1,978 & 1,847 & 2,098 & 2,098 & 1,977 & 1,846 \\
\hline First Stage F-Stat & 24.21 & 23.74 & 22.33 & 15.82 & 22.10 & 21.47 & 20.43 & 14.50 \\
\hline
\end{tabular}

*Alcohol abuse is defined as the number of days that an individual had five or more drinks on a single occasion. Robust standard 
Table 5. 2SLS Results. Second Stage.

\begin{tabular}{|c|c|c|c|c|c|c|c|c|}
\hline VARIABLES & $\begin{array}{c}\text { (1) } \\
\text { Hit } \\
\text { Partner }\end{array}$ & $\begin{array}{c}(2) \\
\text { Hit } \\
\text { Partner }\end{array}$ & $\begin{array}{c}\text { (3) } \\
\text { Hit } \\
\text { Partner }\end{array}$ & $\begin{array}{c}\text { (4) } \\
\text { Hit } \\
\text { Partner }\end{array}$ & $\begin{array}{c}5) \\
\text { Violent } \\
\text { towards } \\
\text { Partner } \\
\end{array}$ & $\begin{array}{c}6) \\
\text { Violent } \\
\text { towards } \\
\text { Partner } \\
\end{array}$ & $\begin{array}{c}7) \\
\text { Violent } \\
\text { towards } \\
\text { Partner } \\
\end{array}$ & $\begin{array}{c}8) \\
\text { Violent } \\
\text { towards } \\
\text { Partner } \\
\end{array}$ \\
\hline Alcohol Abuse* & $\begin{array}{l}-0.000 \\
(0.033)\end{array}$ & $\begin{array}{c}0.004 \\
(0.034)\end{array}$ & $\begin{array}{c}0.030 \\
(0.034)\end{array}$ & $\begin{array}{c}0.029 \\
(0.043)\end{array}$ & $\begin{array}{c}0.021 \\
(0.040)\end{array}$ & $\begin{array}{c}0.021 \\
(0.042)\end{array}$ & $\begin{array}{c}0.018 \\
(0.042)\end{array}$ & $\begin{array}{c}0.035 \\
(0.053)\end{array}$ \\
\hline Age & & $\begin{array}{l}-0.010 \\
(0.008)\end{array}$ & $\begin{array}{l}-0.012 \\
(0.008)\end{array}$ & $\begin{array}{l}-0.011 \\
(0.008)\end{array}$ & & $\begin{array}{c}0.004 \\
(0.009)\end{array}$ & $\begin{array}{c}0.002 \\
(0.010)\end{array}$ & $\begin{array}{l}-0.003 \\
(0.009)\end{array}$ \\
\hline Age 21 or Older & & $\begin{array}{c}0.017 \\
(0.032)\end{array}$ & $\begin{array}{c}0.035 \\
(0.031)\end{array}$ & $\begin{array}{c}0.039 \\
(0.032)\end{array}$ & & $\begin{array}{c}-0.034 \\
(0.038)\end{array}$ & $\begin{array}{c}-0.002 \\
(0.038)\end{array}$ & $\begin{array}{c}0.022 \\
(0.038)\end{array}$ \\
\hline White & & $\begin{array}{c}0.049 * * \\
(0.024)\end{array}$ & $\begin{array}{c}0.017 \\
(0.025)\end{array}$ & $\begin{array}{c}0.013 \\
(0.027)\end{array}$ & & $\begin{array}{c}0.046 \\
(0.028)\end{array}$ & $\begin{array}{c}0.039 \\
(0.030)\end{array}$ & $\begin{array}{c}0.031 \\
(0.032)\end{array}$ \\
\hline Hispanic & & $\begin{array}{l}-0.016 \\
(0.023)\end{array}$ & $\begin{array}{c}0.006 \\
(0.023)\end{array}$ & $\begin{array}{c}0.002 \\
(0.023)\end{array}$ & & $\begin{array}{l}-0.028 \\
(0.027)\end{array}$ & $\begin{array}{l}-0.022 \\
(0.027)\end{array}$ & $\begin{array}{l}-0.037 \\
(0.026)\end{array}$ \\
\hline $\begin{array}{l}\text { Years of } \\
\text { Education }\end{array}$ & & $\begin{array}{l}-0.001 \\
(0.005)\end{array}$ & $\begin{array}{c}0.003 \\
(0.005)\end{array}$ & $\begin{array}{c}0.003 \\
(0.005)\end{array}$ & & $\begin{array}{l}-0.001 \\
(0.006)\end{array}$ & $\begin{array}{c}0.004 \\
(0.006)\end{array}$ & $\begin{array}{c}0.007 \\
(0.006)\end{array}$ \\
\hline Ever Married & & $\begin{array}{c}0.029 \\
(0.033)\end{array}$ & $\begin{array}{c}0.042 \\
(0.032)\end{array}$ & $\begin{array}{c}0.044 \\
(0.033)\end{array}$ & & $\begin{array}{l}-0.004 \\
(0.039)\end{array}$ & $\begin{array}{l}-0.027 \\
(0.038)\end{array}$ & $\begin{array}{l}-0.015 \\
(0.039)\end{array}$ \\
\hline First Income Quintile & & $\begin{array}{l}-0.040 \\
(0.032)\end{array}$ & $\begin{array}{l}-0.027 \\
(0.033)\end{array}$ & $\begin{array}{l}-0.020 \\
(0.033)\end{array}$ & & $\begin{array}{l}-0.006 \\
(0.038)\end{array}$ & $\begin{array}{c}0.001 \\
(0.040)\end{array}$ & $\begin{array}{c}0.004 \\
(0.040)\end{array}$ \\
\hline Second Income Quintile & & $\begin{array}{c}0.002 \\
(0.029)\end{array}$ & $\begin{array}{c}0.008 \\
(0.031)\end{array}$ & $\begin{array}{l}-0.002 \\
(0.030)\end{array}$ & & $\begin{array}{c}0.019 \\
(0.034)\end{array}$ & $\begin{array}{c}0.002 \\
(0.035)\end{array}$ & $\begin{array}{l}-0.032 \\
(0.034)\end{array}$ \\
\hline Third Income Quintile & & $\begin{array}{l}-0.022 \\
(0.030)\end{array}$ & $\begin{array}{l}-0.021 \\
(0.031)\end{array}$ & $\begin{array}{l}-0.007 \\
(0.033)\end{array}$ & & $\begin{array}{l}-0.001 \\
(0.035)\end{array}$ & $\begin{array}{l}-0.005 \\
(0.037)\end{array}$ & $\begin{array}{c}0.002 \\
(0.040)\end{array}$ \\
\hline Fourth Income Quintile & & $\begin{array}{l}-0.025 \\
(0.025)\end{array}$ & $\begin{array}{l}-0.026 \\
(0.025)\end{array}$ & $\begin{array}{l}-0.022 \\
(0.028)\end{array}$ & & $\begin{array}{l}-0.017 \\
(0.029)\end{array}$ & $\begin{array}{l}-0.023 \\
(0.029)\end{array}$ & $\begin{array}{l}-0.032 \\
(0.033)\end{array}$ \\
\hline Income Missing & & $\begin{array}{c}0.057 \\
(0.048)\end{array}$ & $\begin{array}{c}0.062 \\
(0.047)\end{array}$ & $\begin{array}{c}0.072 \\
(0.051)\end{array}$ & & $\begin{array}{c}0.091 \\
(0.053)\end{array}$ & $\begin{array}{c}0.091 \\
(0.055)\end{array}$ & $\begin{array}{c}0.073 \\
(0.058)\end{array}$ \\
\hline Dating Problems & & & $\begin{array}{c}0.048 \\
(0.034)\end{array}$ & $\begin{array}{c}0.058 \\
(0.035)\end{array}$ & & & $\begin{array}{c}0.117^{* * *} \\
(0.038)\end{array}$ & $\begin{array}{c}0.118^{* * *} \\
(0.040)\end{array}$ \\
\hline Regret due to Alcohol & & & $\begin{array}{c}0.050 \\
(0.030)\end{array}$ & $\begin{array}{c}0.041 \\
(0.032)\end{array}$ & & & $\begin{array}{l}0.066 \\
(0.034)\end{array}$ & $\begin{array}{l}0.056 \\
(0.037)\end{array}$ \\
\hline Depress & & & $\begin{array}{c}0.019 \\
(0.015)\end{array}$ & $\begin{array}{c}0.023 \\
(0.015)\end{array}$ & & & $\begin{array}{c}0.012 \\
(0.018)\end{array}$ & $\begin{array}{c}0.016 \\
(0.018)\end{array}$ \\
\hline Stress & & & $\begin{array}{c}0.055 \\
(0.056)\end{array}$ & $\begin{array}{c}0.009 \\
(0.054)\end{array}$ & & & $\begin{array}{c}0.082 \\
(0.062)\end{array}$ & $\begin{array}{c}0.082 \\
(0.065)\end{array}$ \\
\hline Ever Smoked & & & & $\begin{array}{c}-0.025 \\
(0.035)\end{array}$ & & & & $\begin{array}{l}-0.035 \\
(0.042)\end{array}$ \\
\hline Marijuana Last Year & & & & $\begin{array}{c}0.005 \\
(0.033)\end{array}$ & & & & $\begin{array}{c}0.007 \\
(0.040)\end{array}$ \\
\hline Index of Risk Taking & & & & $\begin{array}{l}-0.001 \\
(0.003)\end{array}$ & & & & $\begin{array}{l}-0.001 \\
(0.004)\end{array}$ \\
\hline Ever Gamble & & & & $\begin{array}{c}0.018 \\
(0.024)\end{array}$ & & & & $\begin{array}{c}0.008 \\
(0.028)\end{array}$ \\
\hline Play Lottery & & & & $\begin{array}{c}0.003 \\
(0.023)\end{array}$ & & & & $\begin{array}{c}-0.054^{* *} \\
(0.026)\end{array}$ \\
\hline Constant & $\begin{array}{c}0.171^{* * *} \\
(0.045)\end{array}$ & $\begin{array}{c}0.366 \\
(0.201)\end{array}$ & $\begin{array}{c}0.290 \\
(0.200)\end{array}$ & $\begin{array}{c}0.284 \\
(0.178)\end{array}$ & $\begin{array}{c}0.222^{* * *} \\
(0.054)\end{array}$ & $\begin{array}{c}0.145 \\
(0.238)\end{array}$ & $\begin{array}{c}0.078 \\
(0.238)\end{array}$ & $\begin{array}{c}0.171 \\
(0.207)\end{array}$ \\
\hline Observations & 2,100 & 2,100 & 1,978 & 1,847 & 2,098 & 2,098 & 1,977 & 1,846 \\
\hline First Stage F-Stat & 24.21 & 23.74 & 22.33 & 15.82 & 22.10 & 21.47 & 20.43 & 14.50 \\
\hline
\end{tabular}

*Alcohol abuse is defined as the number of days that an individual had five or more drinks on a single occasion. Robust standard errors in parentheses

$* * * \mathrm{p}<0.01, * * \mathrm{p}<0.05$ 
Table 7. Robustness Check: Have 4 or more Drinks on One Occasion as the Measure of Alcohol Abuse.

\begin{tabular}{|c|c|c|c|c|c|c|c|c|}
\hline VARIABLES & $\begin{array}{c}\text { (1) } \\
\text { Hit Partner }\end{array}$ & $\begin{array}{c}(2) \\
\text { Hit Partner }\end{array}$ & $\begin{array}{c}\text { (3) } \\
\text { Hit Partner }\end{array}$ & $\begin{array}{c}(4) \\
\text { Hit Partner }\end{array}$ & $\begin{array}{c}(5) \\
\text { Violent towards } \\
\text { Partner }\end{array}$ & $\begin{array}{c}\text { (6) } \\
\text { Violent towards } \\
\text { Partner } \\
\end{array}$ & $\begin{array}{c}\text { (7) } \\
\text { Violent towards } \\
\text { Partner }\end{array}$ & $\begin{array}{c}(8) \\
\text { Violent towards } \\
\text { Partner } \\
\end{array}$ \\
\hline \multicolumn{9}{|c|}{ Panel A: OLS Results } \\
\hline Alcohol Abuse & $\begin{array}{c}0.012^{* * *} \\
(0.004)\end{array}$ & $\begin{array}{c}0.011^{* * *} \\
(0.004)\end{array}$ & $\begin{array}{c}0.013^{* * * *} \\
(0.004)\end{array}$ & $\begin{array}{c}0.011^{* *} \\
(0.005)\end{array}$ & $\begin{array}{c}0.014 * * * \\
(0.004)\end{array}$ & $\begin{array}{c}0.013^{* * * *} \\
(0.004)\end{array}$ & $\begin{array}{c}0.014^{* * * *} \\
(0.005)\end{array}$ & $\begin{array}{c}0.014^{* * * *} \\
(0.005)\end{array}$ \\
\hline \multicolumn{9}{|c|}{ Panel B: 2SLS Results } \\
\hline Alcohol Abuse & $\begin{array}{l}-0.001 \\
(0.034)\end{array}$ & $\begin{array}{c}0.003 \\
(0.033)\end{array}$ & $\begin{array}{c}0.029 \\
(0.034)\end{array}$ & $\begin{array}{c}0.030 \\
(0.044)\end{array}$ & $\begin{array}{c}0.020 \\
(0.041)\end{array}$ & $\begin{array}{c}0.020 \\
(0.041)\end{array}$ & $\begin{array}{c}0.016 \\
(0.042)\end{array}$ & $\begin{array}{c}0.037 \\
(0.054)\end{array}$ \\
\hline Observations & 2,097 & 2,097 & 1,975 & 1,846 & 2,095 & 2,095 & 1,974 & 1,845 \\
\hline First Stage F-Stat & 23.46 & 25.41 & 22.20 & 14.90 & 21.35 & 23.06 & 20.31 & 13.59 \\
\hline
\end{tabular}

Robust standard errors in parentheses

$* * * \mathrm{p}<0.01, * * \mathrm{p}<0.05$ 
Table 8. Robustness Check: Binary Measure of Alcohol Abuse.

\begin{tabular}{|c|c|c|c|c|c|c|c|c|}
\hline VARIABLES & $\begin{array}{c}\text { (1) } \\
\text { Hit } \\
\text { Partner }\end{array}$ & $\begin{array}{c}(2) \\
\text { Hit Partner }\end{array}$ & $\begin{array}{c}\text { (3) } \\
\text { Hit Partner }\end{array}$ & $\begin{array}{c}\text { (4) } \\
\text { Hit } \\
\text { Partner }\end{array}$ & $\begin{array}{c}(5) \\
\text { Violent } \\
\text { towards } \\
\text { Partner }\end{array}$ & $\begin{array}{c}(6) \\
\text { Violent } \\
\text { towards } \\
\text { Partner }\end{array}$ & $\begin{array}{c}(7) \\
\text { Violent } \\
\text { towards } \\
\text { Partner }\end{array}$ & $\begin{array}{c}(8) \\
\text { Violent } \\
\text { towards } \\
\text { Partner }\end{array}$ \\
\hline \multicolumn{9}{|c|}{ Panel A: OLS Results } \\
\hline Alcohol Abuse & $\begin{array}{c}0.046^{* * *} \\
(0.017)\end{array}$ & $\begin{array}{c}0.043 * * \\
(0.017)\end{array}$ & $\begin{array}{c}0.047^{* * * *} \\
(0.018)\end{array}$ & $\begin{array}{c}0.037 \\
(0.020)\end{array}$ & $\begin{array}{c}0.058 * * * \\
(0.019)\end{array}$ & $\begin{array}{c}0.056 * * * \\
(0.020)\end{array}$ & $\begin{array}{c}0.050 * * \\
(0.020)\end{array}$ & $\begin{array}{c}0.054 * * \\
(0.022)\end{array}$ \\
\hline \multicolumn{9}{|c|}{ Panel B: 2SLS Results } \\
\hline Alcohol Abuse & $\begin{array}{c}-0.001 \\
(0.210)\end{array}$ & $\begin{array}{c}0.022 \\
(0.197)\end{array}$ & $\begin{array}{c}0.167 \\
(0.193)\end{array}$ & $\begin{array}{c}0.191 \\
(0.284)\end{array}$ & $\begin{array}{c}0.129 \\
(0.250)\end{array}$ & $\begin{array}{c}0.122 \\
(0.239)\end{array}$ & $\begin{array}{c}0.101 \\
(0.232)\end{array}$ & $\begin{array}{c}0.229 \\
(0.343)\end{array}$ \\
\hline Observations & 2,100 & 2,100 & 1,978 & 1,847 & 2,098 & 2,098 & 1,977 & 1,846 \\
\hline First stage F-stat & 13.26 & 14.90 & 15.14 & 8.193 & 12.36 & 13.55 & 14.05 & 7.590 \\
\hline
\end{tabular}

Robust standard errors in parentheses

$$
* * * \mathrm{p}<0.01, * * \mathrm{p}<0.05
$$


Appendix Table 1. Questions Used to Generate Some of the Control Variables.

Attitudes towards Risk/Impulsivity:

I often try new things just for fun or thrills, even if most people think they are a waste of time.

When nothing new is happening, I usually start looking for something exciting.

I often do things based on how I feel at the moment.

I sometimes get so excited that I lose control of myself.

I like it when people can do whatever they w ant, without strict rules and regulations.

I often follow my instincts, without thinking through all the details.

1 not true

2 a little true

3 somewhat true

4 pretty true

5 very true 
Appendix Table 2. Robustness Checks: 15 Days Sample and 45 Days Sample.

\begin{tabular}{|c|c|c|c|c|c|c|c|c|}
\hline VARIABLES & $\begin{array}{c}(1) \\
\text { Hit Partner }\end{array}$ & $\begin{array}{c}(2) \\
\text { Hit Partner }\end{array}$ & $\begin{array}{c}(3) \\
\text { Hit Partner }\end{array}$ & $\begin{array}{c}(4) \\
\text { Hit Partner }\end{array}$ & $\begin{array}{c}(5) \\
\text { Violent towards } \\
\text { Partner } \\
\end{array}$ & $\begin{array}{c}(6) \\
\text { Violent towards } \\
\text { Partner } \\
\end{array}$ & $\begin{array}{c}(7) \\
\text { Violent towards } \\
\text { Partner } \\
\end{array}$ & $\begin{array}{c}(8) \\
\text { Violent towards } \\
\text { Partner } \\
\end{array}$ \\
\hline \multicolumn{9}{|c|}{ Panel A: 15 Days Sample: OLS Results } \\
\hline Alcohol Abuse & $\begin{array}{c}0.013 * * \\
(0.006)\end{array}$ & $\begin{array}{c}0.012 * * \\
(0.006)\end{array}$ & $\begin{array}{c}0.013 * * \\
(0.006)\end{array}$ & $\begin{array}{c}0.012 \\
(0.007)\end{array}$ & $\begin{array}{c}0.018^{* * *} \\
(0.006)\end{array}$ & $\begin{array}{c}0.016^{* * *} \\
(0.006)\end{array}$ & $\begin{array}{c}0.018^{* * *} \\
(0.006)\end{array}$ & $\begin{array}{c}0.023^{* * * *} \\
(0.008)\end{array}$ \\
\hline \multicolumn{9}{|c|}{ Panel B: 15 Days Sample: 2SLS Results } \\
\hline Alcohol Abuse & $\begin{array}{c}-0.076 \\
(0.136)\end{array}$ & $\begin{array}{c}-0.035 \\
(0.106)\end{array}$ & $\begin{array}{c}-0.034 \\
(0.135)\end{array}$ & $\begin{array}{c}-0.022 \\
(0.118)\end{array}$ & $\begin{array}{c}0.045 \\
(0.142)\end{array}$ & $\begin{array}{c}0.030 \\
(0.118)\end{array}$ & $\begin{array}{c}0.029 \\
(0.149)\end{array}$ & $\begin{array}{c}0.050 \\
(0.131)\end{array}$ \\
\hline Observations & 1,042 & 1,042 & 975 & 910 & 1,043 & 1,043 & 977 & 911 \\
\hline \multicolumn{9}{|c|}{ Panel C: 45 Days Sample: OLS Results } \\
\hline Alcohol Abuse & $\begin{array}{c}0.010 * * * \\
(0.003)\end{array}$ & $\begin{array}{c}0.010 * * * \\
(0.004)\end{array}$ & $\begin{array}{c}0.012^{* * *} \\
(0.004)\end{array}$ & $\begin{array}{c}0.010 * * \\
(0.004)\end{array}$ & $\begin{array}{c}0.009 * * \\
(0.004)\end{array}$ & $\begin{array}{c}0.008 * * \\
(0.004)\end{array}$ & $\begin{array}{c}0.008 * * \\
(0.004)\end{array}$ & $\begin{array}{c}0.009 * * \\
(0.004)\end{array}$ \\
\hline \multicolumn{9}{|c|}{ Panel D: 45 Days Sample: 2SLS Results } \\
\hline Alcohol Abuse & $\begin{array}{c}0.142 \\
(0.090)\end{array}$ & $\begin{array}{c}0.141 \\
(0.092)\end{array}$ & $\begin{array}{c}0.196 \\
(0.108)\end{array}$ & $\begin{array}{c}0.229 \\
(0.133)\end{array}$ & $\begin{array}{c}0.084 \\
(0.089)\end{array}$ & $\begin{array}{c}0.079 \\
(0.091)\end{array}$ & $\begin{array}{c}0.117 \\
(0.097)\end{array}$ & $\begin{array}{c}0.124 \\
(0.107)\end{array}$ \\
\hline Observations & 2,803 & 2,803 & 2,641 & 2,472 & 2,796 & 2,796 & 2,635 & 2,466 \\
\hline
\end{tabular}

